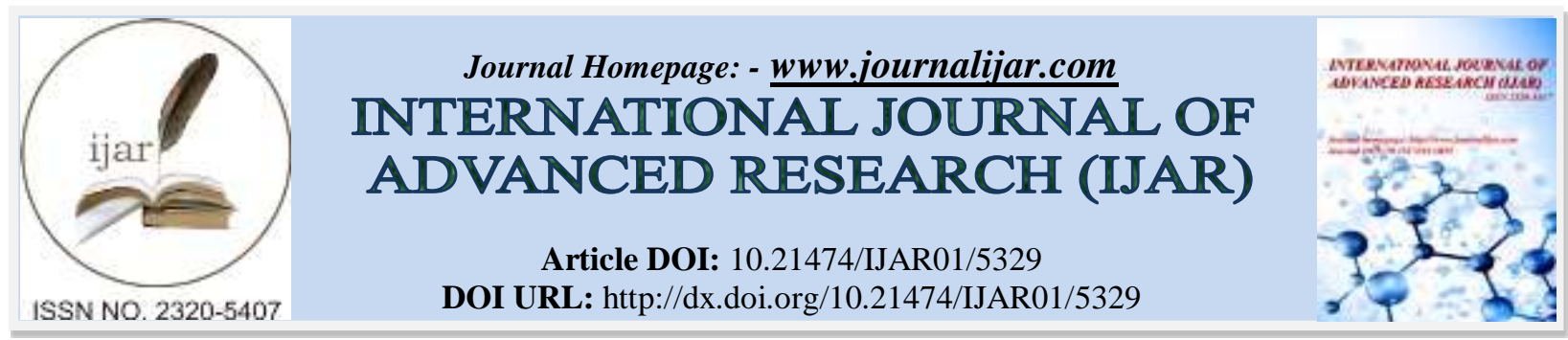

RESEARCH ARTICLE

\title{
MONITORING ANTHROPOCENE EPOCH IN THE MAHANADI BASIN AND CHILIKA LAGOON, INDIA.
}

Dr. Siba Prasad Mishra ${ }^{1}$ and Saswat Mishra ${ }^{2}$.
1. Civil Engineering Department, Centurion University of Technology \& Management Jatni, Bhubaneswar, 752050.

2. Civil Engineering Department, Centurion University of Technology \& Management Jatni, Bhubaneswar, 752050.

\section{Manuscript Info}

Manuscript History

Received: 04 July 2017

Final Accepted: 06 August 2017

Published: September 2017

Key words:-

Anthropocene, Mahanadi, GHG, GDP,

Geohydrology, Chilika lagoon.

\section{Abstract}

The Anthropocene epoch in geological time scale has taken over the Holocene epoch where the human forcing has dominated the nature. The activities and growth in population have changed the geosphere. biosphere and atmosphere. The Mahanadi river basin and Chilika lagoon are of areas $141589 \mathrm{Km}^{2}$ and $1165 \mathrm{~km}^{2}$ respectively in peninsular central India near tropic of cancer. The basin has changed its geomorphology/biodiversity after the $1^{\text {st }}$ nuclear test in 1945 by way of change in population, climate, drainages, land use, land cover, mining and carbon level. In India, many species have become extinct or critically endangered during the Anthropocene. The present study investigates those exemplary changes in the Mahanadi basin due to changes in its demography, rainfall, temperature, carbon dioxide level, GHG gases, mineral mediation, geohydrology, hydro-chemistry, social, economic and political fronts in the new Epoch. The states Chhattisgarh and Odisha in the basin have undergone exponential changes after missile activities in Odisha, the super cyclone, Tsunami2004, massive mining exploration, high GDP growth in Chhattisgarh, acute sedimentation in Chilika Lagoon, erosion and accretion along coast and changes in mean sea level, and other natural calamities. The devastating floods in 1982 and 2008, hottest sun on $5^{\text {th }}$ June $2003\left(50^{\circ}\right.$ C) at Titlagarh, Killer heat waves in 1998, unstable sea, slamming severe storms, abnormal increase in lightning fatalities, human mediated minerals and new health hazards are marked events of the Anthropocene in the basin. The present study is to record the changes, their causes and action to be taken to manage the adverse effects.

Copy Right, IJAR, 2017,. All rights reserved.

\section{Introduction:-}

Anthropo (human) cene (new) epoch (period) is a neologism in the geological encyclopedia introduced by Crutzen, Stoermer, (2000) ${ }^{[1]}$. The new eon has succeeded the 11500 years old Holocene (entirely recent) on $16^{\text {th }}$ August, 1945 after first test of nuclear explosion. The nodal agency, International Commission on Stratigraphy (ICS), has not officially acknowledged the Anthropocene epoch, though the new eon is universally accepted. The misperception between the delineation of Chrono-stratigraphic unit and Geo-chronologic units have made the proposal of declaring 
the new epoch rather political than scientific Zalasiewicz et al $(2014)^{[2]}$. The geospatial shift of the epoch has been proposed to be in four phases, (a) post Holocene (the priming,1000 BC to $1850 \mathrm{AD}$ ) (b) the margin (1850 to 1944 AD) (c) the fundamental shift (1945 to 1980 AD) (d) the acceleration (1981 AD and continuing) Mishra, (2017) ${ }^{[3]}$. The stratigraphy of the epoch is location specific and human centric.

About 12 anthropogenic parameters such as global warming, GHG emissions, mineral mediation, bio-signatures, acidification of ocean, eutrophication, industrialization, urbanization and deforestation etc., results in habitat loss, species invasions, predation, mineralogical, geomorphologic and many chemical changes Davos (2004) ${ }^{[4}$. The main anthropogenic signatures of Anthropocene observed are hydrologic interventions, changes in energy consumption, over exploitation of ground water, changes in residence time of elements, Limnology and lithology, GDP/NSDP, extinct and extirpation of species. The 12 natural indicators of the earth's systems are rainfall, floods/droughts, carbon level changes, earth quakes, Tsunamis, volcanism, oceanic disturbances, landslides, coastal erosion, avalanche and PHAs, NEAs.

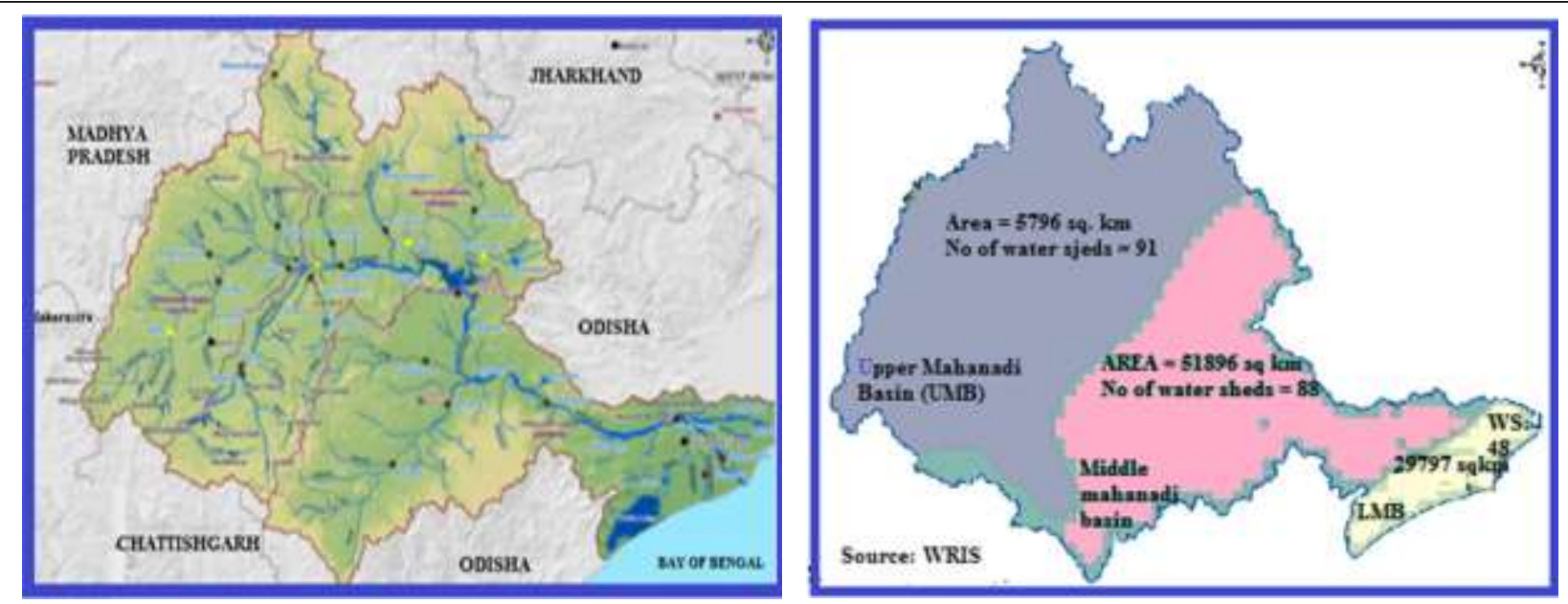

Fig 1(a):- The political map of Mahanadi Basin and Chilika Lake (b) the zoning of the basin (Source: CWC India)

The Epochs in past:-

The earth has passed through five extinction phases due to big ice ages (glaciations) in Paleo record, the Huronian (2.4 to 2.1 billion years BP), the Cryogenian (720 to 635 million years BP), the Andean-Saharan (450 to 420 million years BP), the late Paleozoic ice age (335 to 260 million years BP) and the Quaternary (2.7 million to 65years BP) http://www. livescience.com /5840. The little ice ages (glacial) and warmer periods (inter glacial) occur within the glaciations at a regular intervals. The cycle repeats in about 41000 years given by Milankovitch Mishra S P 2017 $7^{[5]}$, Gupta S, M. (2010) ${ }^{[6]}$. The cycle signifies changes in the earth's orbit around the sun, climate changes of the earth due to its eccentricity (Changing shape of orbit from near circle to oval), its wobble (slowly spinning top) in every 19000 to 23000 years, and the tilt obliquity (principal axis tilt 24.5 to $22.1^{\circ}$ in 41000 years). Holocene epoch existed for 11700 years only. The span of Holocene is much less than any of the cycles proposed by Milankovitch. Whether the Homosapiens has made such dynamic change in the geological stratigraphy?

\section{Non-availability long term records:-}

The meteorological, geologic and hydrologic records and even historical signatures for analysis and prediction are available for 1 to 2 centuries only for the Mahanadi basin. Prediction of future climate needs long term time series which is not available practically. The researcher analyses various proxy records, marine sediments, strand lines or isotope techniques preserved in glacial paleo environment. Foraminifera and Radiolaria indicate the past MSL and temperature which are subtle to parameters related to climate Campisano, $(2012)^{[7]}$. The cataclysmic events of past recorded in history can be reconstructed to assess the basin. Eleven parallel paleo sand ridges and blurred five strand lines are identified up to $35 \mathrm{~km}$ inland within the delta which were washed away by floods, and wetland to swamps (Sar lake $8.1 \mathrm{~km}^{2}$ and Samang Pat $3.5 \mathrm{~km}^{2}$ ), few lacustrine area, islands and channels got gradually depleted in and around Chilika lake within $85^{0}$ East ridge and EGB Hills Mishra et al., $(2016)^{[8]}$.

Reasons for study:- The National Green Tribunal alleged that the river Mahanadi is polluted and dying slowly due to hydrologic interventions and influx of municipal wastes. The 8 major and 34 medium irrigation projects and four 
(under construction) in Chhattisgarh could not control the floods rather dry up the river Mahanadi in upper Mahanadi basin (UMB).

All the dams in the upper basin of Mahanadi (UMB) got depleted at present. Like other deltas of world Mahanadi delta is shrinking and sinking as dams upstream arrests $66.7 \%$ of sediment in $21^{\text {st }}$ century Mishra S P (2016) ${ }^{[9]}$. The federal govt. in the basin has allowed water supply to large number of Industries which were not provided in the water schedule of the dam projects during project planning.

The Super TPP set up at Lara in Chhattisgarh by NTPC shall affect 27villages in Jharsuguda in middle Mahanadi basin (MMB) with smoke, dust and GHG's (Times of India TNN, $1^{\text {st }}$ Jan, (2016). The heavy extraction of ores and minerals in Odisha and Chhattisgarh made the basin polluted today. The water of the river Mahanadi is heavily polluted and even unfit for agriculture in summer.

Ill planned and miss-coordinated management of the basin has resulted in some man made floods in the past. Paucity of water head for hydro-power and unavailability for agriculture water during Rabi crops are common in the basin. However anastomosed irrigation system in the basin and the delta has eradicated the famine in the basin from the date of inception of the Anthropocene.

The sedimentation, pollution and shrimp culture in the Chilika lagoon have downsized it and affected the economic stability of the stake holders. The social, economic and political turmoil of the area urged the lake users for migration and marginalization Mishra S. P. $(2015)^{[5]}$.

The present study is monitoring the causes and the impacts of anthropogenic and climatic changes in the basin during the Anthropocene period. The possible management of the ill effects of Anthropocene and curative attributes is also discussed.

\section{The Mahanadi Basin:-}

The Mahanadi basin ( $80^{\circ} 30^{\prime}$ to $86^{\circ} 50^{\prime}$ E Long and $19^{\circ} 21^{\prime}$ to $23^{\circ} 35^{\prime}$.N Lat.), in the East Coast India was an outcrop of rifting and break up of Gondwana land of Antarctica during late Jurassic to early Cretaceous period. This sedimentary river basin has catchment area of $141589 \mathrm{Km}^{2}$. The runoff drain mainly through the Chhattisgarh states $\left(75136 \mathrm{Km}^{2}\right)$, and Odisha $\left(65580 \mathrm{~km}^{2}\right)$ supporting a population of 1.577 millions (Fig 1). Geomorphologic classification of the basin is the Upper Mahanadi basin (UMB), Middle Mahanadi Basin (MMB) and the lower Mahanadi Basin (LMB) Mishra et al (2015) ${ }^{[10]}$, Fig-1(b). The basin has maximum elevation of $1321 \mathrm{~m}$ whereas MMB has elevation of $(100$ and $750 \mathrm{~m})$ but major portion lies in elevation range of 200 to $400 \mathrm{~m}$.

The $851 \mathrm{~km}$ long river has reduced its annual average discharges $66.88 \mathrm{BCum}$ in past to $41.57 \mathrm{BCum}$ at present (CWC data from 1993-2012) draining to Bay of Bengal between Paradip and Chilika. The average annual sediment load of the river has decreased from 26.95 MMT in 1980-84 (Delta development plan, Govt. Of Odisha, 1986) ${ }^{[11]}$ to 10.723 MMT during 1993-2012 as per CWC GOI data. Similarly 20\% and 18\% of the ground water (GW) are harnessed from available 13.678 MCM and 23.09 BCM respectively in Chhattisgarh and Odisha respectively (WR Deptt, Raipur) and in Odisha (CGWB, Odisha). The drainage density of the basin is low (0.022) up to 700kms indicating the soil has high resistivity, permeable, thick vegetative forest cover and low relief (WR Dept, Odisha).

The basin covers 45 districts of Odisha, Chhattisgarh Jharkhand and Maharashtra. There are, 253 dams (small to large), 14 barrages, 13 weirs, one Lift, six power houses, two cuts and a tidal inlet constructed during the Anthropocene epoch in the basin Fig 2 (a). The LU and LC of the basin as per 2005-06 data Bhuban, NRSC, HYD. are built-up land $4677 \mathrm{~km}^{2}$, forest $46356 \mathrm{~km}^{2}$, agricultural land $76838 \mathrm{~km}^{2}(54.27 \%)$, waste land $7423.8 \mathrm{~km}$ and water bodies of $6294 \mathrm{~km}^{2}(4.45 \%)$. The soils in the basin are red, yellow, mixed red and black, laterite and deltaic CWC, $(2014)^{[12]}$ (Fig 1(c)

\section{The Mahanadi delta:-}

The arcuate shaped Mahanadi delta has average inland length of $72 \mathrm{~km}$, coastal length $200 \mathrm{~km}$ and a spread of 9500 $\mathrm{km}^{2}$ Fig 3(b). The entire delta is lacustrine, flood plains, swamps, lagoons or alluvial land mass with Paddy, casunuts and coconut as the major products. In 1900, during pre-epoch, Cuttack was the only city in the delta but in the last century two major cities and six major townships have developed indicating the anthropogenic stress over the delta. The delta had been sunk and shrunk with eroded coast line and polluted river water Fig 3 (b). 


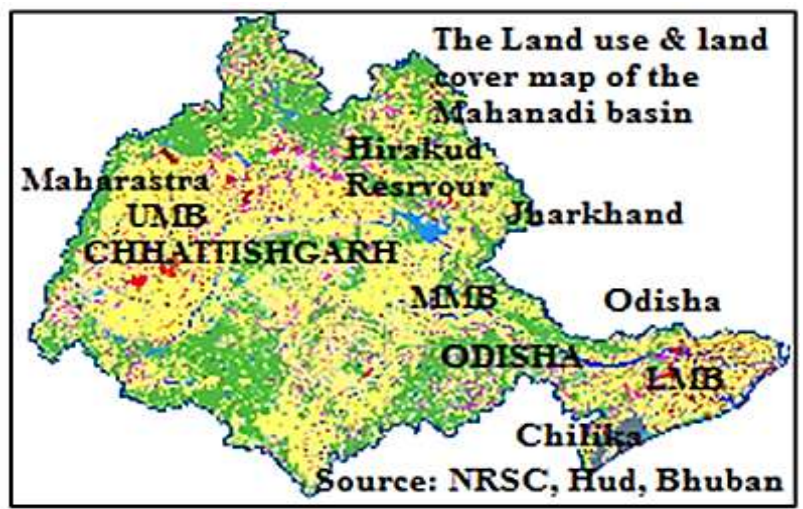

Fig 1 (C): LU/LC map of the Mahanadi basin
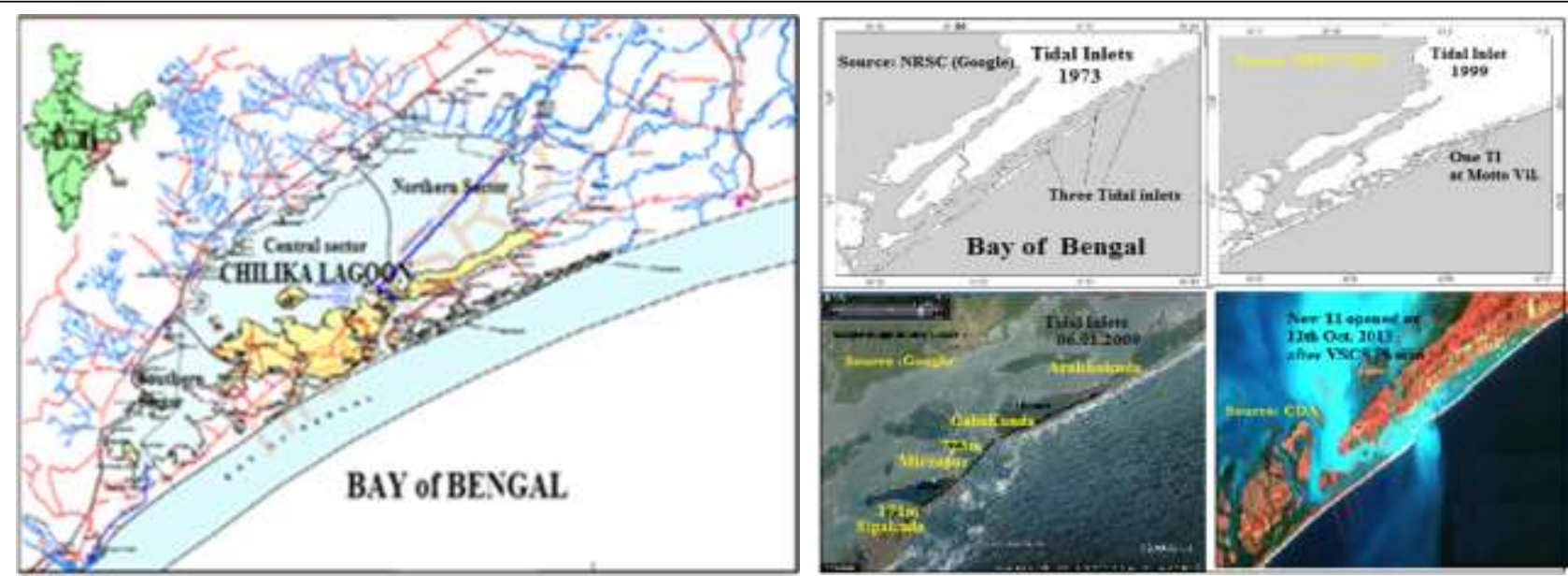

Fig 2 : Chilika lagoon, position of tidal inlets at various phases from 1973 to 2013 (Source : CDA, Odisha)

\section{Chilika lagoon:-}

The Chilika, $\left(19^{\circ} 28^{\prime}-54^{\prime} \mathrm{N}\right.$. lat. and $85^{\circ} 05^{\prime}-85^{\circ} 38^{\prime} \mathrm{E}$. long.), a gulf in pre-Holocene, formed its spit from south 2500-3000 years BP and became a lagoon lying in the southern corner of Mahanadi delta. Gradually sedimentation downsized the lagoon from $1500 \mathrm{~km}^{2}$ to $1165 \mathrm{~km}^{2}$ and even less and threatened its ecology and biodiversity. Poor flow exchange and shifting of tidal inlets have brought a debate about the conversion of the brackish lagoon to a fresh water one like Koleru lake in Andhra Pradesh the prototype and death of Aral lake in middle east.
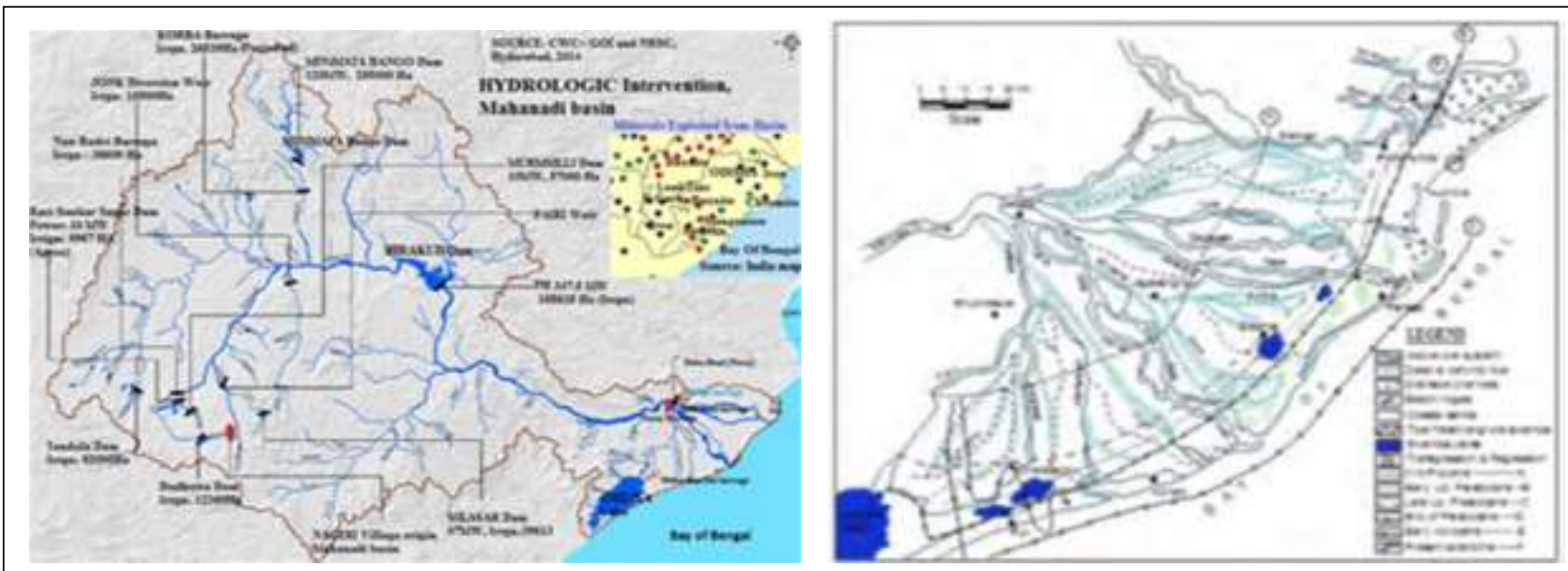

Fig 3(a):The hydrologic/mineralogy intervention in the Mahanadi basin (b) The strand lines in Mahanadi delta (CWC -2014) 
The impact of sedimentation in the lagoon, were conversion of $393 \mathrm{~km}^{2}$ from lacustrine area to land (1920 to 1993 ), reduction in average depth from $3 \mathrm{~m}$ to $1.6 \mathrm{~m}$ (1922 to 2000) and disappearance of about $40 \%$ of brackish water species (1920 to 1999), (Pattanaik S 2001) ${ }^{[13]}$. The aqua catch of the lagoon was $8924 \mathrm{MT}$ in $1986-87,1274 \mathrm{MT}$ in 1995-96 and enhanced to 12000MT in 2009-10 after dredging of Sipakuda mouth. (CDA report, 2001 \& 2012 , www.cda.com) ${ }^{[14]}$. Shrimp/prawn culture, tourism activities, gherry bunds and effluents from the inflowing rivers have polluted the lagoon. Degradation in catch, economic instability, antisocial activities and political enforcements has induced migration, occupational shifts and marginalization of the 0.8 million stake holders in and around the lagoon. The high floods, shifting of inlets to north and depletion of inlets are causing resolution and regeneration of islands/isles within the lagoon (Fig 2 (a).and (b)

\section{Review of Literature:-}

The new geological epoch, Anthropocene, in geological time scale is a misnomer. A few literatures are available in this topic. Bastia et al., (2016) ${ }^{[15]}$ reported that the annual discharge and sediment flow from Mahanadi basin to Bay of Bengal from 1980-2010 was about $49 \pm 20.5$ to $41 \pm 16 \mathrm{Km} 3$ /year and $17.4 \pm 12.7$ MMT to $12 \pm 5 \mathrm{MMT}$. The mean annual erosion rate of the UMB is 34.59MT/Ha//year, $25.84 \mathrm{MT} / \mathrm{Ha} / /$ year in MMB and 8.35 MT/Ha/year (Mishra et al 2017). Panda et al., (2006) reported the proliferation of weeds in Lake were $70 \mathrm{Km} 2$ and $300 \mathrm{Km}^{2}$ in the year 1975 and 2000 before the new mouth by GIS studies. Bhatta et al $(2017)^{[16]}$, reported that fuel wood consumption has decreased in India. The Low fuel wood value index (FVI) in India is of Chhattisgarh (4.37 m/t) and Odisha is $(4.84 \mathrm{~m} / \mathrm{t})$. Highest annual Carbon dioxide emission was recorded in UP (31.4 MT) and lowest in Chhattisgarh (7.19 MT) in 2015.

Chaturvedi B. K. $(2016)^{[17]}$ has mentioned that $80 \%$ of 85.0 billion people living in villages in India use wood and cow dung as fuel which may cause asphyxiation deaths due to indoor smoke. Earth system research laboratories, Hawaii are recording $\mathrm{CO}_{2}$ level from 1958 and found that by 2014 the rate of increase was @ 1.47 ppm/year. Per capita $\mathrm{CO}_{2}$ emission in India was 0.27 and 1.92 MT in the years 1960 and 2014 respectively, Business standard, 9th May 2015. Balsubramanian, (2011) ${ }^{[18]}$ have reported that $\mathrm{CO}_{2}$ level was $280 \mathrm{ppm}$ in 1850 's which have risen up to 413 ppm in 2014. Similarly the MSL rise @ 3.2mm/year shall submerge many islands in future. Jena P. P. et al., $(2014)^{[20]}$, reported there is increased trend of rainfall in Mahanadi basin. The transportation reach contribute more to the increasing trend in southern part of basin which is to be studied whether anthropogenic or Natural network. Naik et al $(2008)^{[19]}$ reported that the weed spread area in the Chilika $20 \mathrm{Km}^{2}$ in 1972 has increased to $523 \mathrm{~km}^{2}$ in Oct 2000 and in May 2001 the weed free area was $506 \mathrm{Km}^{2}$. The sea grass area has increased from $248 \mathrm{Km}^{2}$ to $86.84 \mathrm{~km}^{2}$ after opening of dredged mouth at Sipakuda, Fadanvis et al., (2016) ${ }^{[21]}$ reported the trend in $\mathrm{CO}_{2}$ fluxes was $-1.85 \pm 2.3 \%$ year $(\mathrm{TgC} \mathrm{yr}-1)$ in CT-2010, over Mahanadi basin.

Ghose et al,. 2011 ${ }^{[22]}$ stated that there is $14 \%$ decrease in sediment over a decade due to anthropogenic activities. The dissolved load is $<25 \%$ of the total sediment load. Globevnik Lidija et al, 2003 ${ }^{\text {[23], informed anthropogenic }}$ activities enhance natural process of erosion and source for sediment influx to river runoff. But dams cause subsidence in deltas for paucity in availability of sediment due to retention Syvitski et al, 2005 ${ }^{[24]}$, 2009 ${ }^{[25]}$. The River Mahanadi has reduced $67 \%$ of sediment quantity to its delta in recent years, Gupta et al, 2012 ${ }^{[26]}$. Soil erosion rate in the Mahanadi basin fluctuate from 116 to $940 \mathrm{~T} / \mathrm{km} 2 / \mathrm{yr}$ Chakrapani (2014), Sodhaganga ${ }^{\text {[27] }}$ whereas the erosion rate in the delta is 200 to $400 \mathrm{MT} / \mathrm{Km}^{2}$. The River Mahanadi carries average $15.74 \mathrm{MMT}$ of sediments annually to the Bay Mohanty M. $(2005)^{[28]}$.

\section{The Impact of Anthropocene:-}

\section{Universal Anthropogenic activity:-}

Atomic explosion is a global phenomenon, but have tremendous stimulation on the local stratigraphic, atmospheric state and had caused anthropogenic ratifications. The Anthropocene epoch have been shifted from $16^{\text {th }} \mathrm{July} 1945$ with the first nuclear test by US, followed by USSR (1949), UK (1952), France (1960) and China (1964).Nuclear tests are conducted underground, earth surface and under water at various depths. US has done the highest number of nuclear tests followed by Soviet Union. (https://skep tical science. com/nuclear.).The T-Sar mega bomb of $50 \mathrm{Mega}$ Ton capacity (about 3800 times the capacity of Hiroshima explosion) tested by Soviet Union (Oct 30 ${ }^{\text {th }}$, 1980) was the largest and followed by a three stage 25 mega tone among the atomic tests by USA in 1960.The date of first atom bomb test $16^{\text {th }}$ July 1945 is considered as the last day of the Holocene epoch in the Mahanadi basin, India and October $30^{\text {th }} 1980$ is taken as the date of great acceleration in Anthropocene, Fig 4 (a) and Fig 4(b). 


\section{Demographic growth in the basin:-}

The globe had a population of 1.2 billion in 1850 which is about 7 billion today. The increase has led to massive destruction of forests, living, nonliving, lithology, mineralogy and nature. The increase has been noticed from 1945 after the first nuclear explosion Fig 4(a).

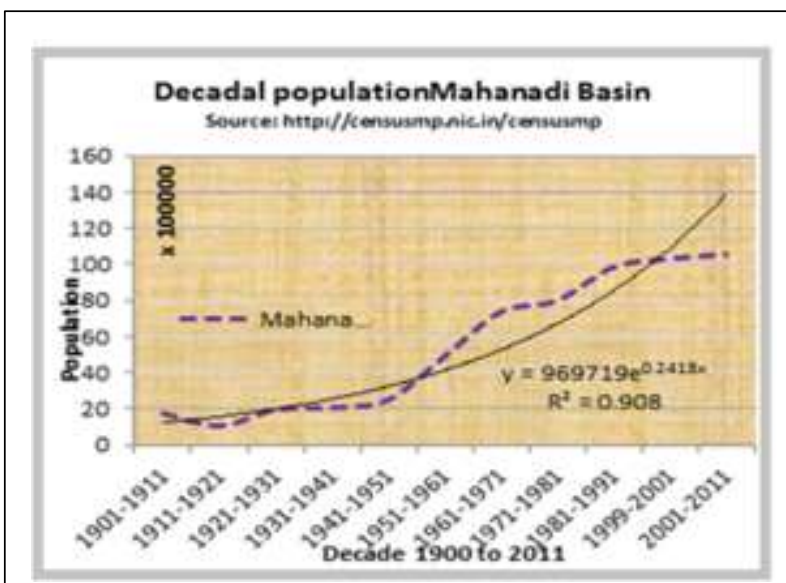

Figure 4: (a) Decadal growth of population of Odisha and C-garh

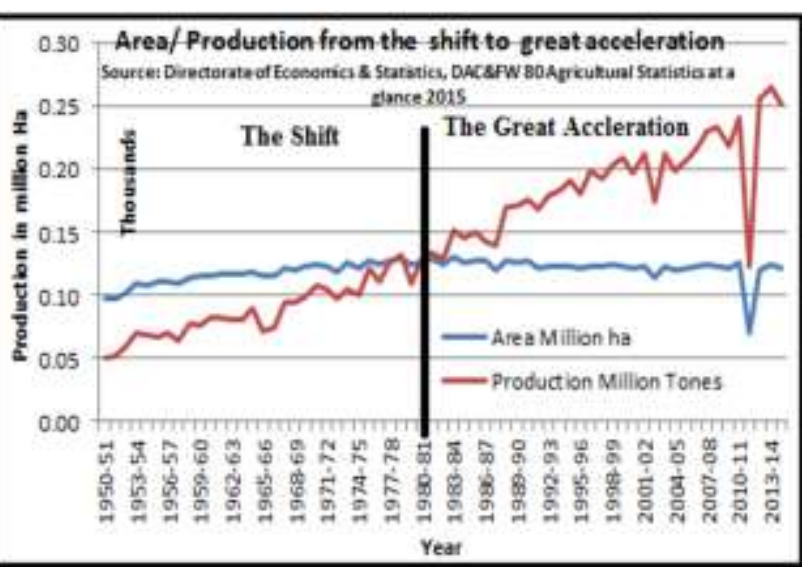

(b) Area vs. Production in the Mahanadi basin

The decadal growth of population is exponential. There is a kink in the \% decadal growth curve from 1940's and 1980's Fig 4(B). The rate of rise is urban population is ever increasing whereas the rural population is having a downward trend from the year 1980 onwards. The population and area in 45 districts in/outside the basin which get the benefit are in UMB is 24616510 and 73214 covering 15 districts of Chhattisgarh, 3640 and $145.66 \mathrm{Km}^{2}$ in one district in Jharkhand, four districts in MP (4210364 and $\left.151.67 \mathrm{Km}^{2}\right)$ and two districts in Maharashtra 2395449 and $322.39 \mathrm{Km}^{2}$ and MMB/LMB covers 23 districts having population and area of 31255225 and $65847 \mathrm{~km}^{2}$ in Odisha (CWC data 2014).

\section{Livestock and Poultry:-}

The livestock in the middle and lower Mahanadi basin has remained constant throughout the basin 1951 to 2012 where as in India there is increasing trend Fig 5(a). Interestingly the poultry statistics the graph exhibits increasing trend in the Mahanadi basin. The poultry is growing at a higher rate by hormonal application which may cause hormonal disorder and lead to different types of cancers Fig 5 (a).

\section{Climatic changes in the basin:-}

Climatic changes are natural but influenced by human forcing. The basin is in peninsular central India and lies towards south of Tropic of cancer, drenched by $75-80 \%$ average south west monsoon gives average rainfall of $1292 \mathrm{~mm}$ in Chhattisgarh and $1489 \mathrm{~mm}$ in Odisha with a tropical weather. The average temperature trend in the margin and shift was cyclic but is of increasing trend overall by $0.1-0.2^{0} \mathrm{C}$ annually during the acceleration Fig 5 (b).

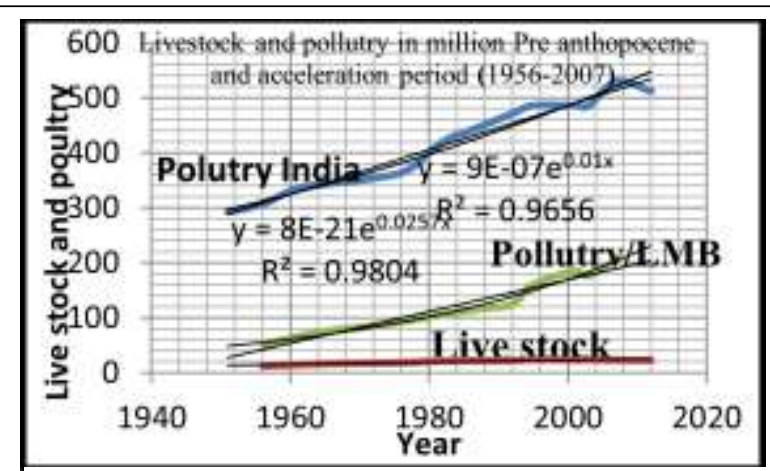

Figure 5(a): Livestock/Poultry in LMB,MMB/India

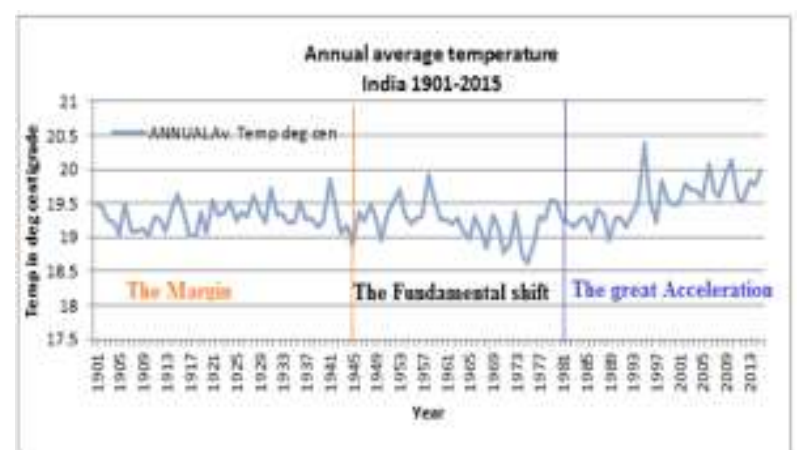

Fig 5(b): Changes in annual av. Temperature India (Source: NIC)

Rate of change of temperature was @ $0.35^{\circ} \mathrm{C} / 100$ years (IMD report) where as in Mahanadi basin it was @ $1.1^{0} \mathrm{C}$ $/ 100$ years which are 2 times the average temperature of India. No prominent changes observed in precipitation in 
the basin Rao, P. G. $2009^{[29]}$. Temperature, $\mathrm{CO}_{2}$ level and rainfall play pivotal role in climatic change. But IPCC, $\mathrm{AR} 5^{[30]}$ projects a probable rise in temperature of the upper Mahanadi basin up to $2^{0} \mathrm{C}$ by $2050 \mathrm{Fig} 5$ (b). There shall be decline in rainfall; increase in maximum summer temperature. Failure of monsoon shall cause more drought and untimely high floods. The change of climate from mid Holocene to present is in the Table 1.

During the pre-Anthropocene epoch there was wet spell in the basin, during shift it was dry period. But during the acceleration there was increase in precipitation, severe cyclonic storms and frequent floods in the basin. The highest recorded annual rainfall in the basin in 1994, was $1780 \mathrm{~mm}$. The basin had six spells of heavy rainfall and 6 floods at the delta head in 1994 (Fig 5 (b).The lowest annual rainfall was 900mm during the dry spell in the basin was in 1979.

Table 1:- Changes in climate from mid-Holocene to present (Anthropocene Epoch)

\begin{tabular}{|c|c|c|c|c|}
\hline BP & Geological Age & Temp./Sun spot & Climatic changes & Reference \\
\hline & MID HOLOCENE & & & \\
\hline $\begin{array}{l}700- \\
5000\end{array}$ & Iron age & High Temp. & Dry climate, Low lake levels & $\begin{array}{l}\text { Antonsson et al } \\
08^{[30]}\end{array}$ \\
\hline $\begin{array}{l}500- \\
4000\end{array}$ & Climatic optimum & Short warm period & $\begin{array}{l}\text { Drop in sea level, Cooling \& } \\
\text { drying, Indian lakes and rivers } \\
\text { dried up, Island formation }\end{array}$ & Naidu P D $1999^{[31]}$ \\
\hline \multirow[t]{2}{*}{$\begin{array}{l}4000- \\
3500\end{array}$} & Vedic Era & Less hot & $\begin{array}{l}\text { Moist, good rainfall, large sedges } \\
\text { (solid grass like plants), Joining } \\
\text { of Chilika Gulf, Daya \& Bhargovi }\end{array}$ & Naidu P D $1999^{[31]}$ \\
\hline & POST HOLOCENE & & & \\
\hline $\begin{array}{l}3500- \\
2600\end{array}$ & $\begin{array}{l}\text { Iron age/Egyptian } \\
\begin{array}{l}\text { Minoan } \\
\text { period. }\end{array}\end{array}$ & $\begin{array}{l}\text { SBO(Sub-boreal } \\
\text { climatic optimum }\end{array}$ & $\begin{array}{l}\text { Abrupt climate change, Sea level } \\
\text { drop by } 3 \mathrm{~m} \text { to } 2 \mathrm{~m} \text { Wet/cold event } \\
\text { Variable ENSO }\end{array}$ & \\
\hline $\begin{array}{l}2600- \\
2150\end{array}$ & $\begin{array}{l}\text { Egyptian Minoan } \\
\text { Warm period. }\end{array}$ & $\begin{array}{l}\text { SAP (Pessimum of } \\
\text { subantlatic) }\end{array}$ & $\begin{array}{l}\text { Abrupt climate change } \\
\text { Cooling, ENSO was variable }\end{array}$ & \\
\hline $\begin{array}{l}2150- \\
1850\end{array}$ & $\begin{array}{l}\text { Roman warm era } \\
(1800-1850)\end{array}$ & $\begin{array}{l}\text { Warming trend, } \\
\text { Dalton Minimum }\end{array}$ & Abrupt climate change & \\
\hline $\begin{array}{l}1850 \\
-1350\end{array}$ & Little ice age & $\begin{array}{l}\text { Maunder minimum. } \\
(1650-1750)\end{array}$ & Abrupt climate change, Cooling & Mann-2002 $2^{[32]}$ \\
\hline $\begin{array}{l}1350- \\
750\end{array}$ & $\begin{array}{l}\text { Little climatic } \\
\text { Medieval optimum } \\
\text { Medival warm } \\
\text { period }\end{array}$ & $\begin{array}{l}\text { Warm summer } \\
\text { (Av temp > } \\
\text { 1deg today }\end{array}$ & $\begin{array}{l}\text { Abrupt climate change, MSL } \\
2 \mathrm{~m} \text { Low than Present Mild } \\
\text { winter, dry \& warm summer }\end{array}$ & \\
\hline $\begin{array}{l}750- \\
450\end{array}$ & $\begin{array}{l}\text { (MWP):Medieval } \\
\text { warm period }\end{array}$ & Warm summer & $\begin{array}{l}\text { Mild winter, significant cyclones } \\
\text { and Highs }\end{array}$ & Mann- 2002 $2^{[32]}$ \\
\hline $\begin{array}{l}450- \\
200\end{array}$ & -do- & Little Ice age & $\begin{array}{l}\text { Coastal transgression prominent, } \\
1610 \text { AD coolest year in India }\end{array}$ & \\
\hline PRE- & ANTHROPOCENE & EPOCH & Priming & \\
\hline $200-120$ & Present climate & 1910 & Coastal change, Famine and floods & Bradly et al $1992^{[33}$ \\
\hline \multirow[t]{2}{*}{$120-71$} & -do- & Stable, warmer & More floods, Cyclones & Dey $2005^{[34]}$ \\
\hline & ANTHROPOCENE & ЕРОСН & The shift & \\
\hline \multirow[t]{2}{*}{$72-36$} & -do- & Warm summer & $\begin{array}{l}\text { Increased rainfall, the area became } \\
\text { Flood affected to flood vulnerable }\end{array}$ & \\
\hline & ANTHROPOCENE & ЕРОСН & The great acceleration & \\
\hline $35-00$ & Warm period & $\begin{array}{l}\text { Max temp unto } \\
50^{0} \quad \mathrm{C} \text {.Maunder } \\
\text { min. started } 2016 \\
\end{array}$ & $\begin{array}{l}\text { Solar inactivity/ cooling started } \\
\text { From } 2013 \text { but rise in } \\
\text { maximum temperature }\end{array}$ & NASA reports \\
\hline
\end{tabular}

Natural disasters in the basin:-

The Mahanadi basin is prone to flood and drought during the acceleration period. There was severe famine in 1877 and 1897in the priming period. In 2015, the Mahanadi basin observed severe drought 25 districts in UMB (C-garh) 
and 26 districts in (Odisha). The scenario of the flood/drought and impact of El Nino southerly oscillation (ENSO) during Anthropocene epoch (1855-2016) is given in Table 2.

Table 2:- Floods, droughts and El Niño's in Mahanadi basin during priming/shift/ acceleration

\begin{tabular}{|c|c|c|c|c|}
\hline & Flood (Th Cumec) & $\begin{array}{l}\text { Priming (1855-1944) } \\
\text { (Number of years) }\end{array}$ & $\begin{array}{l}\text { The shift (1945-1979) } \\
\text { (Number of years) }\end{array}$ & $\begin{array}{l}\text { The Acceleration (1980- } \\
\text { 2016) (Number of years) }\end{array}$ \\
\hline Flood & Low $(<20$ cumec $)$ & 27 & 9 & 8 \\
\hline \multirow{3}{*}{ Mishra 2016.} & Medium (20-34) & 42 & 22 & 18 \\
\hline & High (34-40) & 10 & 4 & 7 \\
\hline & Very High $(>40)$ & 11 & nil & 3 \\
\hline \multirow[t]{3}{*}{ Drought } & Very severe & 6 & 0 & 2 \\
\hline & Mild & 18 & 8 & 10 \\
\hline & Famine & 2 & & \\
\hline \multirow[t]{3}{*}{ ENSO } & $\begin{array}{l}\text { El Nino } \\
\text { Southerly } \\
\text { oscillation) }\end{array}$ & NA & 8 & 13 \\
\hline & La Nina & NA & 8 & 12 \\
\hline & La Nada & NA & 14 & 13 \\
\hline Bay storms & $\begin{array}{l}\text { Cyclonic } \\
\text { and above }\end{array}$ & $232(1891-1950)$ & $103(1950-1980)$ & $82(1981-2016)$ \\
\hline
\end{tabular}

The Hirakud and other major dams in the basin, according to recent study, the frequency of floods have been increased (from 11.8 years in 1956 to 3.75 years in 1988) and drought frequency in the region has increased. Due to increasing sedimentation the storage capacity of the Hirakud reservoir has been reduced from 8,105 cubic km to 6,427 cubic $\mathrm{km}$ in recent years. From the above analysis it can be inferred that after anthropogenic interventions the low, high and very high floods in the basin were reduced whereas the medium floods had increased due to effective operation of the hydrologic interventions such as dams, barrages etc. Table2. Highest daily rainfall recorded was 582 $\mathrm{mm}$ in Sambalpur in May, 1982 and 2008 caused the highest flood of 44750cumec causing numerous breaches in canals/drainage channels and in 2000, the lowest recorded discharge of 5050 Cumec at delta head of Mahanadi.

El Nino Southerly oscillations (ENSO), La Nina and La Nada (ENSO) have been considered by IMD from 1950 to 2012 there were 23 El Niño years out of which 20 years are la Nina years. Trends of ENSO have contracted for last 50 years and the frequency has reduced from 6 years to 4 years. Bay of Bengal storms have shown more tendencies to slam Odisha coast and pass through the Mahanadi basin rather slamming the AP or WB coast during the acceleration period of Anthropocene.

It is observed that the highest flood year runs with drought in the basin. Ashokan et al $2008^{[31]}$ have studied the flood and drought in the Mahanadi basin and reported that there shall be increase in flood during the month of September and there shall be draught like situation from June and July. Late Victorian Holocausts, an imprint of famine and apocalyptic deaths (Nawank druvikhya) in the Mahanadi basin during late nineteenth century (http://icrier. org/pdf/working_paper_276.pdf). During the new epoch, the basin has never encountered a year under famine. It is observed that very high flood years are the years of drought.

\section{Carbon sinks and Carbon Sequestration:-}

One of the top 10 killers is the air pollution which is the fifth leading cause of death in India. About 620,000 premature deaths in slums and villages caused by stroke, lower respiratory infections, ischemic heart disease chronic obstructive pulmonary disease, trachea, bronchus infection and lung cancer, among the poor's as per Center for Science and Environment in India. The carbon sinks, forests, ocean, soil and atmosphere absorb and store carbon indefinitely and the opposite process is the carbon sequestration. Carbon foot print is the entire quantity of $\mathrm{CO}_{2}$ or its equivalents released from various anthropogenic carbon activities. Carbon emission and sequestration causes carbon imbalances in nature causing climatic changes. Major sources of release of carbon and GHG gases (CO2, $\mathrm{CO}, \mathrm{CH} 4$, oxides of $\mathrm{N} 2$, hydro carbons and CFC's) are burning of bio fuels, coal, fossil fuels, industries and burning of agriculture residues and fermentation of organic products Ramachandra et al, $(2012)^{[32]}$. 
Last 800000 years, the levels of $\mathrm{CO}_{2}$ had fluctuated between 170 to 280ppm which may the difference between Glacial and interglacial gap, Goenka et al (2014) ${ }^{[33]}$. The present change in levels of $\mathrm{CO}_{2}$ is 400 ppm over Antarctica during May 2016. The cause of glaciation or de-glaciation is related to either the changes in the level of $\mathrm{CO}_{2}$ or the temperature changes. The causes of changes in $\mathrm{CO}_{2}$ level are due to modernization and advancement of science and technology. Prevalence of the Anthropocene epoch can be ascertained in the Mahanadi basin. The carbon present in the atmosphere from different sources and total carbon as a whole shows exponential correlation $\left(\mathrm{R}^{2}\right.$ value $\left.>0.9\right)$ is given in Table (a)and (b)

The consequences of rise in level of $\mathrm{CO}_{2}$ level in atmosphere can be one cause for global warming which has resulted in mean sea level rise (MSLR). The pre- Holocene rise of Bay of Bengal by $60 \mathrm{~m}$ along south Odisha coast have been reported from the pollen grain records, Oysters and fossils at $60-70 \mathrm{~m}$ height on the hills at the western bank of Chilika (Ramachandrapur).
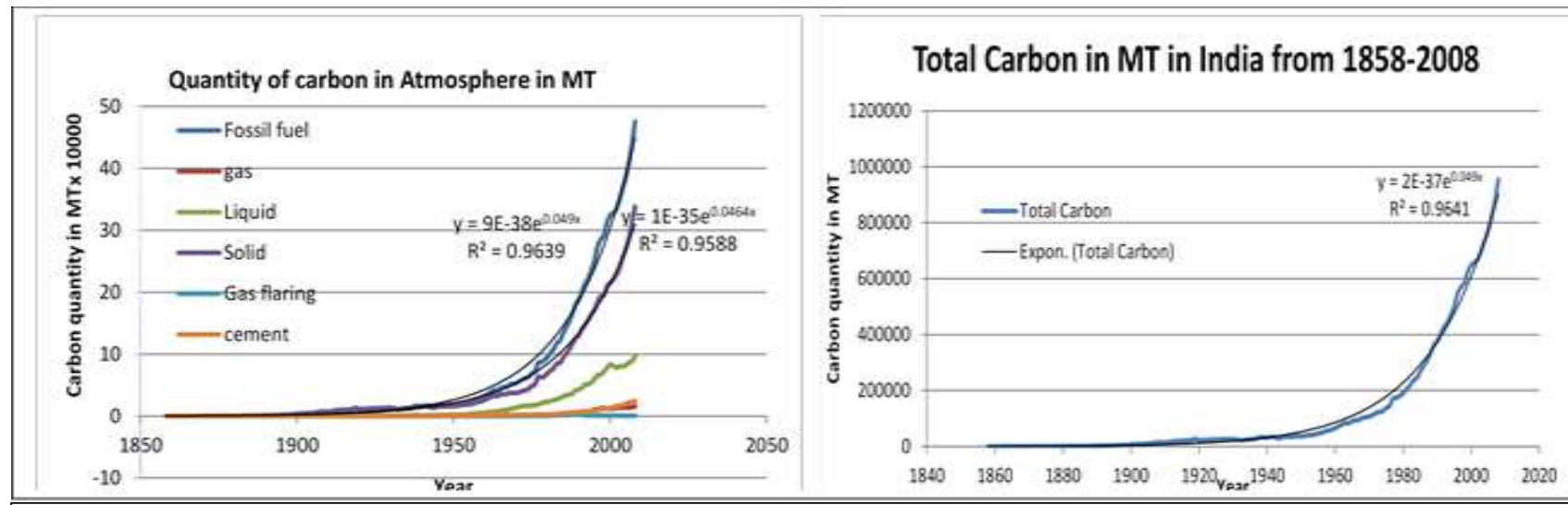

Fig 6 (a) : Exponential rise of Carbon from different sources

(b) total carbon present in atmosphere in India

The basin have future plan of construction of Power plants of capacity 2100 and 1000MW at Korba STPP and Sipat TPP in the Upper Mahanadi basin and 1050 MWMPCL, power plant at Angul. Chhattishgarh (UMB) after becoming an independent state is developing faster and planned to install $10892 \mathrm{MW}$ coal based power plants by different industrial organizations. The $\mathrm{CO}_{2}$, solid waste, fly ash that will be generated shall leave no land in the basin for cultivation.

\section{Anthropocene Geological formations:-}

The Mahanadi basin is enriched with long coast line and natural resources, Mineral reserves in the basin are Bauxite ( $33 \%$ ), iron ore ( $25 \%$ ) and coal $(20 \%)$ of India which made it a hotspot for ports, harbors and lucrative for mining. The UMB is the rice bowl of India and also rich in bauxite, iron, and coal. The resources are overexploited in mining sector for last 35-40years. Jharkhand (250), Chhattisgarh (201), Odisha (173) have numbers of mines respectively out of 3318 in India (till 2014-15). A detailed statistics of the metals and mineral mines in the basin are in Table 3.

Table 3:- Mining of major ores in Mahanadi basin (Odisha and Chhattishgarh) \{Source: India brand equity foundation \}, (www.ibef.org/download/IBEF_CHHATISGARH_260508) and

\begin{tabular}{|l|l|l|l|c|c|c|}
\hline State & Mineral & $\begin{array}{l}\text { Ore reserve in } \\
\text { (India) }\end{array}$ & $\begin{array}{l}\text { No of } \\
\text { mines }\end{array}$ & Extracted/ in MT & $\begin{array}{l}\text { No of } \\
\text { mines }\end{array}$ & Extracted in MT \\
\hline & & MT & \multicolumn{2}{|c|}{2014} & \multicolumn{2}{|c|}{2015} \\
\hline Odisha & Bauxite & 3739051000 & 4 & 9091 & 4 & 10839 \\
\hline & Chromite & 321751000 & 21 & 2161 & 20 & 2892 \\
\hline & Garnet & 56963000 & 1 & 11999 & 1 & 14767 \\
\hline & Iron ore & 31323000000 & 68 & 52022 & 64 & 79921 \\
\hline & Lime stone & $1.84935 \mathrm{E}+11$ & 6 & 3409 & 6 & 4501 \\
\hline & manganese & 328111000 & 37 & 326 & 31 & 398 \\
\hline & Sillimanite & 66987 & 1 & 18311 & 1 & 13393 \\
\hline
\end{tabular}




\begin{tabular}{|l|l|l|c|c|c|c|}
\hline & Graphite & 188673000 & 1 & 2082 & 4 & 7783 \\
\hline & Coal & 27791MMT & 2 & 123627 & 2 & 138.461 \\
\hline Chhattisgarh & Bauxite & 96000000 & 13 & 1561 & 10 & 1991 \\
\hline & Iron ore & $10052 \mathrm{MMT}$ & 14 & 29388 & 15 & 24592 \\
\hline & Lime stone & 3580MMT & 63 & 23588 & 65 & 27553 \\
\hline & Tin & 83726166 & 6 & 24685 & 6 & 13541 \\
\hline & Coal & 35375MMT & 11 & 134764 & 11 & 130605 \\
\hline
\end{tabular}

The frustum of earth in the basin is continuously pruned after independence in the name of prosperity and industrial advancement. The major metals are taken out from the frustum of the basin. Instead the wastes, debris, byproducts and new constructions are left behind, making the basin either a concrete jungle or a waste dump. The water in the channels is contaminated with heavy metals and contaminants continuously.

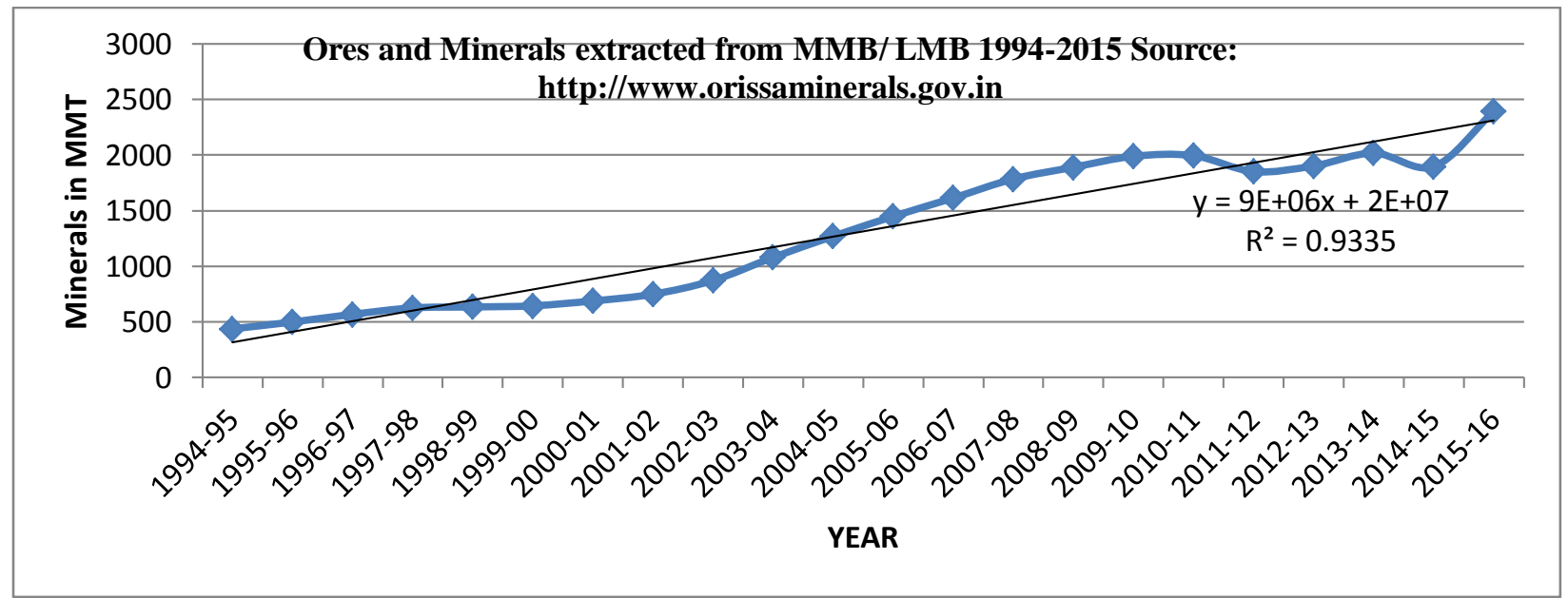

Figure 7:- Extraction of ores and minerals in MMB and UMB of the Mahanadi River

The numbers of Industrial establishments have increased during the period of shift and during the great acceleration it has multifold hike gradually in the basin. As per GOI data the number of factories in Odisha and Chhattisgarh were 3849 (2008-09), 4028 (2009-10), 4894 (2010-11) and 5150 during 2011-12. The industrial wastes are directly discharged to the nearby drain or rivers without any or a little treatment. The wastes increase the pH, BOD and COD value, decreases the DO of water which has deteriorated the Biota and the quality of water. The future coal based power plants $2558 \mathrm{MW}$ and 250MW in the MMB (by Jindal Co) only within 5-10years shall deteriorate the human health of the basin drastically.

\section{Solid wastes and new minerals:-}

Man mediated minerals:-

It is the activities of the Homosapiens that have caused mass extinctions of the living species, oceanic pollution, Nano ethics, and dechronification and many others. Two hundred eight types of minerals are of human mediated juxtaposed new elements found from a total 5208 numbers of minerals today by International Mineralogical Association, Feb, 2017. Yttrium aluminum garnet (YAG) crystals one among them used for magnet, nonabrasive machine parts, silicon chips, machine parts and tools. Cement, concrete, grouts and stucco and many others also man mediated minerals. Plastiglomerate is most common in the Anthropocene era. The major formation of Anthropocene minerals are formed in the dump yards of mining, building areas both old and new, smelter plants, slags, fire zone and plastic wastes. Solid waste dumps, batteries, electronics appliances factories can have new minerals as exposed to weathering.

The total waste generated in India annually 62 MMT in the country. Annually 5.6 MMT is Plastic, 0.17 MMT is from health industries, 7.90 MMT of Noxious waste and 15 lakh MT is e-waste. About 8 MMT plastic products are consumed every year in India (2008) which is expected upsurge to 12 MMT by 2012.Plastic wastes are nonbiodegradable. Fugitive emissions occur during polymerization and shaping to finished products. Burning of plastic with debris produces $\mathrm{CO}, \mathrm{CO} 2$, Dioxins and Furans, oxides of nitrogen, styrene and benzene which are the common 
pollutants. Lead, LDPE and cadmium used for making PET, PVC, DPE, HDPE,PP, PS occur which are noxious. Bhubaneswar City in LMB produces 345.19 MT of solid waste/ day, out of which plastic wastes are 40-45 TPM. Similarly the Ranchi and Raipur city in UMB produces 208.27 and $184.27 \mathrm{MT} /$ day of waste respectively (2005 report). The plastic waste generation in Chhattisgarh and Odisha is 5840 MT/annum (http://cpcb.nic.in/PWMWebsite2015.pdf). The diseases caused by the new minerals mediated by anthropogenic activities are in table 4 .

Table 4:- The new mediated minerals and metalloids ,sources and causing diseases

\begin{tabular}{|c|c|c|c|}
\hline $\begin{array}{l}\text { Name of new } \\
\text { minerals }\end{array}$ & Major constituent & Source & Disease caused \\
\hline $\begin{array}{l}\text { Plastics } \quad \text { (PET, } \\
\text { PVC, } \\
\text { HDPE,PP, PS) }\end{array}$ & $\begin{array}{l}\text { Unsaturated hydrocar- } \\
\text { bons (non-biodegraded } \\
\text { form layers in soils \& } \\
\text { dumping yards) }\end{array}$ & $\begin{array}{l}\text { Domestic waste, } \\
\text { Industrial, Labs \& } \\
\text { recyclable (container, } \\
\text { cables..) }\end{array}$ & $\begin{array}{l}\text { Dioxins on burning affect reproduction, } \\
\text { growth, hormone \& immunity disorder, } \\
\text { cause Asthmatic bronchitis, Affect } \\
\text { agricultural yield, and block drains causing } \\
\text { urban flooding. }\end{array}$ \\
\hline $\begin{array}{l}\text { Plastics in } \\
\text { electronic } \\
\text { equipment's and } \\
\text { circuit boards. }\end{array}$ & $\begin{array}{lr}\text { BFR, } & \text { Benzene } \\
\text { Acrylamide } & \text { Furan, } \\
\text { Bromine flame retarders }\end{array}$ & $\begin{array}{ll}\text { Industry and } \\
\text { domestic waste }\end{array}$ & $\begin{array}{l}\text { Endocrine system disorder, BFR in man } \\
\text { and animals have neuro behavioral } \\
\text { development, thyroid and cancer. }\end{array}$ \\
\hline $\begin{array}{l}\text { Solder, Switches } \\
\text { chips, mother } \\
\text { board, CRT, } \\
\text { Relay } \\
\text {,semiconductors, } \\
\text { Mother boards }\end{array}$ & $\mathrm{Pb}, \mathrm{Cd}, \mathrm{Hg}, \mathrm{Ba}, \mathrm{Be}$ & $\begin{array}{l}\text { Electronic repairs, } \\
\text { industries, shops \& } \\
\text { municipal wastes }\end{array}$ & $\begin{array}{l}\text { Damaging nervous system, Kidney, blood } \\
\text { system, neural system, lever, respiratory } \\
\text { and skin disorders, Heart, spleen, Warts } \\
\text { disease, Lung's cancer etc. }\end{array}$ \\
\hline $\begin{array}{l}\text { Galvanized Steel } \\
\text { plates, Housing, }\end{array}$ & $\mathrm{Cr}$, & $\begin{array}{l}\text { Electronic } \\
\text { municipal } \\
\text { wastes }\end{array}$ & DNA damage, bronchitis, asthma. \\
\hline
\end{tabular}

The anthropogenic new minerals and metals waste formed can cause deadly health hazards, affect agricultural yields, ecology and limnology as given in table below http://chtenvis.nic.in/e-waste.html.Humans, in the name of since technology and advancement have mediated $4 \%$ of the total minerals and metals in the last $19^{\text {th }}$ century. As per National Green Tribunal (2017), India fly ash shall be threat to environment in the basin. The threats are given in Table 5.

Table 5:- Effects of Solid Waste and industrial residues, source and impact on human health (ENVIS Centre: Chhattisgarh Environment Conservation Board, MOEF and CC, GOI)

\begin{tabular}{|c|c|c|c|}
\hline Industrial residues & components & Where produced & Effects on Human \\
\hline $\begin{array}{l}\text { Red Mud (Alumina } \\
\text { plant } 1.2 \mathrm{MMT} \text {, (Vedanta } \\
\text { Soil rich in P, metals, }\end{array}$ & $\begin{array}{l}\mathrm{Fe}_{2} \mathrm{O}_{3} \quad(50 \%), \quad \mathrm{SiO}_{2} \\
(5 \%), \mathrm{Na}_{2} \mathrm{O}(3-4 \%)\end{array}$ & $\begin{array}{l}\text { Aluminum } \\
\text { Industries, } \\
\text { Bayer's process }\end{array}$ & $\begin{array}{l}\text { Fugitive dusts, Red mud Leachates, soil \& } \\
\text { water, crops and yields, skin itching, fauna } \\
\text { loss Benthic smothering }\end{array}$ \\
\hline $\begin{array}{l}\text { Hazardous wastes RSP } \\
\text { (1.3MMT/year) } \\
\text { (Brahmani basin) }\end{array}$ & $\begin{array}{l}\mathrm{Fe}(35 \%) \text { and } \mathrm{Al} \\
(12.5 \%)\end{array}$ & $\begin{array}{l}\text { C-Garh- } 295387 \\
\text { MTA }(2008) \quad \& \\
\text { Odisha }-96830 \\
\text { MTA }(2007)\end{array}$ & $\begin{array}{l}\text { Hossetti et al } 1998^{[34]}, \& \text { Hazardous Waste } \\
\text { Management in India -2009. Non- } \\
\text { availability of Common Hazardous Waste } \\
\text { Treatment, Storage \& Disposal Facility } \\
\text { (TSDF).in Mahanadi Basin }\end{array}$ \\
\hline Fly Ash (2014-15) TPP & $\begin{array}{l}\text { Ni 77.6ppm), Cd (3.4 } \\
\text { ppm), Sb (4.5 ppm), } \\
\mathrm{As}(43.4 \mathrm{ppm}) \mathrm{Cr}( \\
13.6 \mathrm{ppm}) \mathrm{Pb}(56 \mathrm{ppm})\end{array}$ & $\begin{array}{l}\text { Odisha } \\
=10 \mathrm{MMT} \\
\text { C-Garh=22 } \\
\text { MMT }\end{array}$ & $\begin{array}{l}\text { http://www.cea.nic.in/, Senapati }(2011)^{[35]} \\
\text { Respiratory problem, lung cancer Anemia, } \\
\text { hepatic disorder, Gastroenteritis, Skin } \\
\text { cancer, dermatitis, Cancer, Anemia }\end{array}$ \\
\hline Slag (0.828MMT) & $\begin{array}{lrr}\mathrm{SiO}_{2}(33 \%) & \mathrm{Al}_{2} \mathrm{O}_{3} \\
(15 \%) & \mathrm{CaO} & (31 \%) \\
\mathrm{MgO} & (11 \%) & \mathrm{MnO} \\
(0.2) & \mathrm{FeO}(0.5 \%) \\
\mathrm{S}(0.5 \%) & & \end{array}$ & $\begin{array}{l}\text { Odisha 775TMT } \\
\text { C-garh } \\
\text { 2675TMT }\end{array}$ & $\begin{array}{l}\text { Irritation or inflammation- eye contact } \\
\text { skin, discomfort, irritation, and dermatitis- } \\
\text { skin contact, Chronic inhalation: Silicosis: } \\
\text { Carcinogenic, Autoimmune Disease, } \\
\text { Tuberculosis, Renal Disease, Accidents }\end{array}$ \\
\hline Biomedical wastes & needles & $5852 \mathrm{~kg} /$ day & Carcinogenic \& Cytotoxic, Headaches, \\
\hline
\end{tabular}


year 2009-10 )Sharps, Pathological, chemical, Pharmaceutical radio active

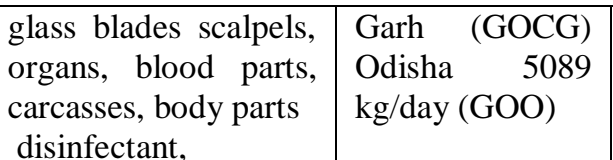

glass blades scalpels, disinfectant, dizziness, weakness Irritation, necrosis, mucous membrane and skin Coughing, chest tightness, increased heart rate, Pulmonary edema pneumonitis ,Toxic

\section{Liquid waste:-}

Liquid Wastes are obtained from domestic washings, chemicals from industries, oils spills, waste water ponds, sludge from industries and other sources. Such wastes may be bio or non-bio degradable, toxic and nontoxic. Disposal of Liquid Waste is done by attenuation, isolation. Jadav et al $2016^{[36]}$ reported that the industrial liquid waste in Chhattisgarh have increased beyond tolerable limit such as electrical conductivity and total dissolved solid were remarkably high. The metals that are essential need for biological growth are cobalt, copper, chromium, iron, magnesium, manganese, molybdenum, nickel, selenium and zinc. Some industrial patches have very high values of $\mathrm{F}-, \mathrm{Na}+, \mathrm{K}+, \mathrm{As}, \mathrm{Cd}, \mathrm{Fe}$, se, $\mathrm{Ni}$ and $\mathrm{Fe}$ which are alarming. Anthropogenic advancement of human in Anthropocene is impossible without iron, steel, plastic and so also energy from coal to fossil fuel which pollutes air. As per US National Library of Medicine, National Institutes of Health 2014, the metals with no proved impact on the biological functions on living are aluminum, antinomy, arsenic, barium, beryllium, bismuth, cadmium, gallium, germanium, gold, indium, lead, lithium, mercury, nickel, platinum, silver, strontium, tellurium, thallium, tin, titanium, vanadium and uranium etc. Heavy metals from the mines, liquid wastes, industries and agriculture shall affect biologic and physiologic functions are in the plants and animals in short and long term are given in the Table 6. The heavy metals $\mathrm{Ni}$ is carcinogenic, , $\mathrm{Zn}$ is an essential nutrient but excess cause Zinc toxicity. Cobalt is needed humans as it is a constituent of vitamin B12, that is medicine for anemia, but excess of Co is harmful to human health.

Table 6:- The biological functions, damages caused with disease by heavy metals in water. (Teachounwou et al $(2014)^{[37]}$, Mohod et al., (2013) ${ }^{[38]}$,

\begin{tabular}{|c|c|c|c|c|c|}
\hline \# & Metal/ limit & sources & Damages & Biological function & diseases \\
\hline 1 & Copper $(\mathrm{Cu})$ & $\begin{array}{l}\text { Most essential nutrient, } \\
\text { soil, industries, }\end{array}$ & $\begin{array}{l}\text { enzyme } \\
\text { activities }\end{array}$ & $\begin{array}{l}\text { Create Hemoglobin } \\
\text { excess cause anemia, } \\
\text { heart diseases, High } \\
\text { B.P }\end{array}$ & $\begin{array}{l}\text { Toxic, Cellular, } \\
\text { tissue damage } \\
\text { lead to Wilson } \\
\text { disease }\end{array}$ \\
\hline 2 & $\begin{array}{l}\text { Arsenic (As) } \\
0.32- \\
1.06 \mathrm{gm} / \mathrm{li} \\
(\mathrm{WHO}-08)\end{array}$ & $\begin{array}{l}\text { Volcanic eruption, } \\
\text { industry products, soil, } \\
\text { pesticides, sheep dips, } \\
\text { preservatives, wood, } \\
\text { dye-stuffs, } \\
\text { conductor }\end{array}$ & Carcinogenic & $\begin{array}{l}\text { Medicines for } \\
\text { syphilis, amoebic } \\
\text { dysentery, yaws, \& } \\
\text { Veterinary drugs }\end{array}$ & $\begin{array}{l}\mathrm{AsO}_{3} \text { treatment } \\
\text { acute leukemia }\end{array}$ \\
\hline 3 & $\begin{array}{l}\text { Cadmium } \quad(\mathrm{Cd}) \\
\mathrm{Cd}=0.005 \mathrm{mg} / \mathrm{lit} \\
(\mathrm{WHO}-08)\end{array}$ & 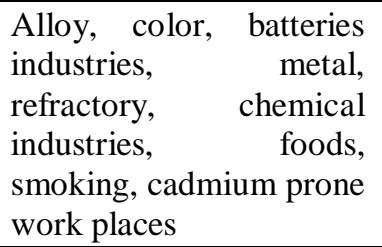 & $\begin{array}{l}\text { cancer, } \\
\text { cytotoxic, } \\
\text { genotoxic and } \\
\text { histopathology } \\
\text { effects liver } \\
\text { kidney }\end{array}$ & $\begin{array}{l}\text { Toxic and } \mathrm{Cd}(\mathrm{VI}) \\
\text { which is manmade is } \\
\text { carcinogenic }\end{array}$ & $\begin{array}{l}\text { Cancer, } \\
\text { Pulmonary } \\
\text { diseases, emp } \\
\text { hysema, osteo } \\
\text { porosis }\end{array}$ \\
\hline 4 & $\begin{array}{l}\text { Lead }(\mathrm{Pb}) 0.05 \mathrm{mg} / \mathrm{li} \\
(\mathrm{WHO}-08)\end{array}$ & $\begin{array}{l}\text { lead-acid batteries, } \\
\text { ammunitions, solder and } \\
\text { pipes), paint, glass, and } \\
\text { devices to shield X-rays }\end{array}$ & $\begin{array}{l}\text { Kidney and } \\
\text { Liver, heart } \\
\text { brain, } \\
\text { reproductive } \\
\text { damages }\end{array}$ & $\begin{array}{l}\text { lead exerts its toxic } \\
\text { effect on the actions } \\
\text { of calcium and to } \\
\text { interact with proteins }\end{array}$ & $\begin{array}{l}\text { lead poisoning of } \\
\text { children, }\end{array}$ \\
\hline 5 & $\begin{array}{l}\text { Mercury } \\
(\mathrm{Hg}) 0.01 \mathrm{mg} / \mathrm{li}(\mathrm{WHO}- \\
8)\end{array}$ & $\begin{array}{l}\text { Available in nature in } \\
\text { three forms (elemental, } \\
\text { inorganic, and organic) }\end{array}$ & $\begin{array}{l}\text { environmental } \\
\text { toxic, } \\
\text { pollutant } \\
\text {,carcinogenic }\end{array}$ & $\begin{array}{l}\text { highly lipophilic, } \\
\text { absorbed by the } \\
\text { lungs \& tissues } \\
\text { lining the mouth }\end{array}$ & Cancer \\
\hline
\end{tabular}

\section{Food security:-}

Last twenty years mal-nourishment has reduced from 40 to $26 \%$ still hunger has taken 200 million lives in the mother earth (World food programme, WFP). The risk for hunger comes out of extreme meteorological events and prolonged climate risks. The scopes of food security and nutrition depend on availability, access, utilization and 
stability of food. The Mahanadi basin is under food instability due to climatic changes and under the impact of the Anthropocene epoch. Weather design is fabricated by climate alterations which threatens food security.

\section{Dying of the basin due to drying:-}

Amidst the interstate dispute of sharing of water of the river Mahanadi, the basin stake holders have forgotten about its quality. Installation of large number of industries and provision for supply of the water from the drainage channels, stagnating the water for many months in large and small lacustrine bodies, not only contaminate its water but also inviting the river is aging and shall dry up slowly. Incision of river and carriage of sediment at a higher concentration claims about juvenility. Average concentration of total suspended solid at Naraj Barrage in 1980's have been reduced from $0.8 \mathrm{mg} / \mathrm{lit}$ to $0.2 \mathrm{mg} / \mathrm{l}$ during monsoon that the basin is drying and dying slowly though climate plays an important role. Odisha has kept provision for $1.435 \mathrm{Bcum} / \mathrm{year}$ or $3.92 \mathrm{Mcum} / \mathrm{day}$ for water supply to townships and industries in the year 2015-16. Allocation of $3.92 \mathrm{MCum}$ of water to township and industries during summer from the river is a herculean task.

\section{Ocean Acidification:-}

Bay of Bengal is more vulnerable and path finder to oceanic acidification. During Oct to Feb the westerly wind carry all the debris (rich in sulphate, Nitrate and $\mathrm{NH}_{3}$ ) blown from land get deposited in the off shore near Coast. These aerosols deplete the $\mathrm{pH}$ value and change the oxidation state of many metals. The near shore water becomes low $\mathrm{pH}$ and become acidic. Coral bleaching occurs which slowdown the growing coral species and reducing fish spawning and feeding areas affecting aqua fauna diversity. Many a planktons and fishes were deprived of food (as primary food chain is distorted) during winter. CSIR (NIO) has reported the depletion rate (@ 0.006 units/year) is much higher than global rate of change, Suguna Meheta, Times of India, $9^{\text {th }}$ May, (2016) .

Nuclear explosion and testing accompanied by exponential increase in population from 1945 onwards have invited global warming, carbon level changes and MSLR. The plant kingdom within oceans started up taking $\mathrm{CO}_{2}$ at higher rate resulted in ocean warming by $0.85^{\circ} \mathrm{C}(1882-2012)$ and sea level rise by $0.19 \mathrm{~m}$ within 1901-2010 MoS \&PI, GOI 2015.

\section{Heat Waves and Cold Waves:-}

The summer starts in the basin from the $4^{\text {th }}$ week of March to end of May. Interestingly numbers of heat wave epochs in the basin is high. Study from IMD only 12 heat waves passed during (1968 to1980) whereas 67 numbers between 1980 to2009 have passed over the basin (http://mospi.nic.in) http://mospi. nic.in/. Hot days and effect of heat waves prevail in April-May. 1998 was the hottest year in the century, the mercury reaching $50^{\circ} \mathrm{C}$ followed by 2008. The frequency of hot days, hot nights and heat waves has abnormally increased during period of great acceleration of the epoch. For the last 15 years annual average mortalities due to hyperthermia in Orissa are 233. The numbers of heat waves that passed over the area was 31 from 1983 to 2016.

\section{Lightning:-}

The lightning deaths in the basin generally occur from March to October @ 250/annum. Direct striking of lightning deaths are 3 to $5 \%$ only, but people die of distant lightning. Causes reported are cardiac and respiratory arrest, vascular spasm, neurologic damages and muscular contractions. The average death rate due to lightning is more than any mortalities against any hazard in Odisha today. Lightning death rate is higher in coastal districts than in other interior Basin. The fatality rate in the State prior to 2000 was even less than 10/annum, but it has increased at present. (OSDMA Report, GOO 2012) ${ }^{[21]}$ in Orissa Fig 8( a). Lightening deaths 2277 in last seven years (SRC Odisha) and by first week of Aug-2017 no of deaths are recorded due to increased upper air cyclic circulations. http://www.business-standard.com/article/news-ians/2-297-killed-by-lightning-in-odisha-in-7-years16090900409_1 


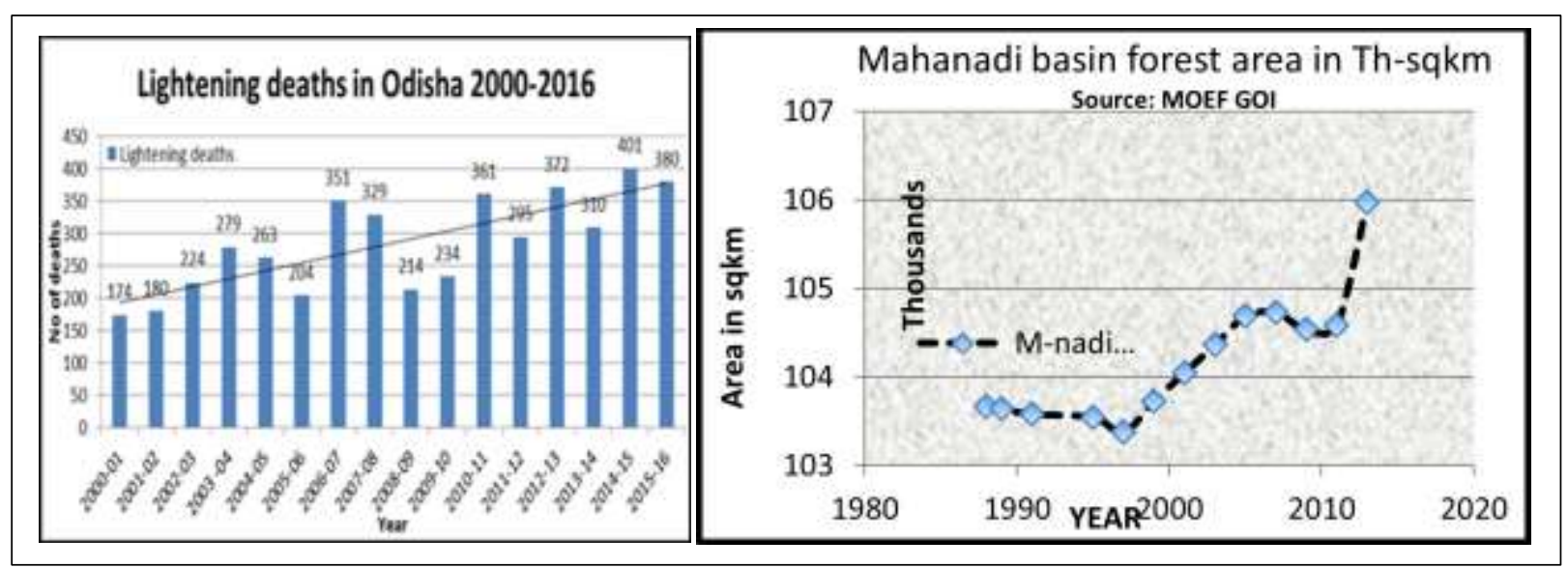

Fig 8 (a ):- Lightening deaths in MMB and LMB Mahanadi R. b) The forest covers in UMB, MMB and LMB of the Mahanadi Basin

\section{Forest area:-}

The UMB was a green state (12\% dense forests of India and 44\% area of Chhattisgarh) with ironic flora, fauna and avifauna of India. The Chhattisgarh (UMB) and Odisha (MMB/LMB) have geographical area $135191 \mathrm{Km}^{2}, 155707$ $\mathrm{Km}^{2}$ respectively out of which large forest cover $\left(\mathrm{CO}_{2}\right.$ sinks) were $3629 \mathrm{Km}^{2}$ and $3986 \mathrm{Km}^{2}$ respectively (India state of forest report 2015) whereas green ness cover were $55621 \mathrm{Km}^{2}$ and $50347 \mathrm{Km}^{2}$ in the year 2013 (GOI data). Mining and quarrying activities, transport, power generation and community development, Industrial and urban growth in the basin are common deteriorating forests, agriculture and human health. It is predicted climate Change leading to warning and water stress shall further exacerbate the degradation which shall have long-term and irreversible adverse socio-economic implications for forest dependent communities and the national economy. But it is seen during the Anthropocene green cover is increasing in the basin

\section{Hydrogeology of the basin:-}

Considering rainfall data 1980 to 2014 , it is found there are negative departures from normal most of the years except 2006 with water level at $2 \mathrm{~m}$ to $10 \mathrm{~m}$ bgwl. The major GW that can be harnessed through Precambrian rocks in $80 \%$ areas in the underground of the basin is $49.99 \mathrm{BCM}(\mathrm{CWC}, 1989)$ The quaternary and tertiary formations in the MMB alluvial belt aquifers in coastal Odisha are fresh but high average values of $\mathrm{Ca} 12 \mathrm{meq} / \mathrm{lit}, \mathrm{Mg} 5.68$ meq1/lit and $\mathrm{HCO}_{3}$ (266mg/lit)are major contaminants. Some aquifers have high pH (8.9) and $\mathrm{EC}$ (20 to $25998 \mathrm{mmho} / \mathrm{cm}$ ) or high values of $\mathrm{Cl}^{-}, \mathrm{NO}_{3}{ }^{-}$and $\mathrm{F}^{-}$which are detrimental to human health Mishra S P. (2016) ${ }^{[42]}$. The basin even has a block, Krishna Prasad which is deprived of irrigation even from ground water. There is rise in $\mathrm{GW}$ level of 2 to $4 \mathrm{~m}$ in the NW part of the basin due to irrigation while in the deltas it is $<2 \mathrm{~m}$.(CWC report)

\section{Vector diseases:-}

A large number of vector diseases like malaria, dengue, chikungunya fever, Japanese encephalitis (JE) and Acute Encephalitis Syndrome (AES), Cholera, diarrheal disease, Enteric Fever (Typhoid), in the Mahanadi basin are the killers. The details of cases of different vector diseases in the basin are given in Table7 (National Vector Borne Disease Control Programme (NVBDCP), Ministry of Health). Dengue has taken 35 lives in Odisha (MMB and LMB) by $3^{\text {rd }}$ Aug 2017 and 13 AES deaths have been recorded by Aug 2017 but 473 acute encephalitis syndrome (AES) cases diagnosed in Odisha. Dengue had taken lives of 42 infants in Odisha during 2016 (The New Indian Express.html, $2^{\text {nd }}$ Sept 2017)

Table 7:- Spread of diseases (cases/deaths) during acceleration period in the Mahanadi basin

\begin{tabular}{|c|c|c|c|c|c|c|}
\hline Fever Cases & 2007 & 2008 & 2009 & 2010 & 2011 & 2012 \\
\hline Malaria(+ve) & & $94803 / 4$ & $104055 / 11$ & $120080 / 47$ & $107472 / 42$ & $90924 / 90$ \\
\hline C-garh & & $329631 / 239$ & $336047 / 198$ & $35028 / 247$ & $281577 / 99$ & $244503 / 79$ \\
\hline Dengue Odisha & $4 / 0$ & $0 / 0$ & $0 / 0$ & $29 / 5$ & $1816 / 33$ & $2255 / 0$ \\
\hline (C-garh & $0 / 0$ & $0 / 0$ & $26 / 7$ & $4 / 0$ & $313 / 11$ & $45 / 0$ \\
\hline Chikungunya Odisha & 4065 & 4676 & 2306 & 544 & 236 & 129 \\
\hline (C-garh) & No report & No report & No report & No report & No report & No report \\
\hline
\end{tabular}




\begin{tabular}{|c|c|c|c|c|c|c|}
\hline$J E /(A E S)$ & No report & No report & No report & No report & No report & No report \\
\hline C-garh & & N/A & N/A & N/A & N/A & N/A \\
\hline Cholera & $35 / 0$ & N/A & $0 / 0$ & $2 / 0$ & $0 / 0$ & $0 / 0$ \\
\hline C-garh & $10 / 0$ & $0 / 0$ & $3 / 0$ & $12 / 0$ & $1 / 0$ & N/A \\
\hline Diarrheal Odisha & $455004 / 68$ & $535028 / 76$ & $663651 / 91$ & $681659 / 104$ & $632493 / 143$ & N/A \\
\hline C-garh & $125463 / 11$ & $149531 / 37$ & $125069 / 11$ & $51480 / 2$ & $64575 / 5$ & N/A \\
\hline Typhoid, Odisha & $26734 / 22$ & $40153 / 32$ & $50341 / 33$ & $45692 / 29$ & $59903 / 104$ & N/A \\
\hline C-garh & $38854 / 0$ & $40231 / 0$ & $53291 / 5$ & $38532 / 0$ & $42115 / 1$ & N/A \\
\hline Kalajar & No report & No report & No report & No report & No report & No report \\
\hline C-garh & No report & No report & No report & No report & No report & No report \\
\hline
\end{tabular}

\section{Deterioration ecology in past/present:-}

In past the earth's atmosphere there was only a mix of all the gasses present today except oxygen but more carbon dioxide. Before $2.45 \mathrm{Ma}$ (Achaean era) a type of single celled structures (Cyanobacteria) formed di-oxygen as a waste product which produced Oxygen which is very reactive started seep carbon from the dead organism and deplete it quickly Emspak,2017.

Carolyn Gramling, 2017 ${ }^{[39]}$, pointed out that during the great oxidation, the bacteria's formed are either iron oxidizing bacteria or cyanobacteria. The oxygen formed by those cyanobacteria affect Hematite ores to make sponge like perforation in the stone which can be easily exhibited in the laterite cover in the Mahanadi basin. It is also observed that there is no growth of planktons and aquatic life in the laterite mines in the basin.

The very severe cyclonic storm Phailin $\left(5^{\text {th }}-14^{\text {th }}\right.$ Oct 2013) smashed the biodiversity, water quality, phytoplankton species and ecology of the lagoon. The strong return waves $15^{\text {th }}$ Oct 2013 reformed the salinity, ammonia and silicate structure at different rate in different sectors $\left(16^{\text {th }}\right.$ Nov, 2014, Times of India).There were changes in the food chain resulting in formation of fresh water toxic cyanobacteria's in the northern sector. Presently the blue green algae species have propagated to the outer channel in patches. The toxic and anaerobic cyanobacteria form a protective layer and has become detrimental the enriched fish kingdom of the largest lagoon of Asia and $2^{\text {nd }}$ largest of the world, the Chilika lagoon.

\section{Economics and Population growth:-}

The GDP of the UMB state grew at a compound annual growth rate (CAGR) of $11.83 \%$ to 36.6 billion US\$ whereas the net state domestic product (NSDP) grew at a CAGR of $10.21 \%$ to 26.9 billion US\$ during 2004-05 and 2015-16. The state has remarkable development in its industrial sector after its formation. Similarly the LMB state had GSDP of $6.1 \%$ in 2015-16 which have been improved to $7.94 \%$ against national average $7.1 \%$. The GDP of the MMB and LMB state grew at a CAGR of $10.25 \%$ to 50.8 billion US\$ whereas the NSDP grew at a CAGR of 10.37 $\%$ to 26.9 billion US\$ during 2004-05 and 2015-16. This growth in GSDP and NSDP indicate there is ample excavation of mineral products and industrial processing running parallel to Anthropocene activities in the basin.

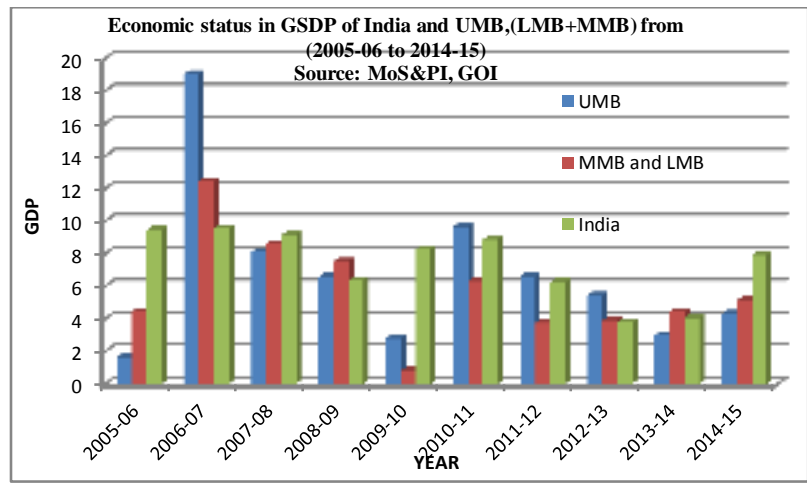

Fig 9(a): The GSDP graph of UMB, MMB/LMB and India \& India

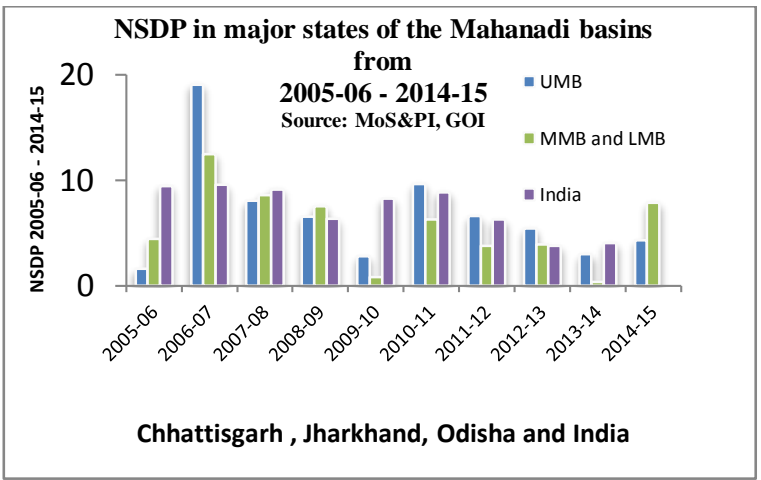

Fig 9(b): NSDP in major states in Mahanadi Basin

\section{Management of Anthropocene in Mahanadi basin:-}




\section{Lacking hydrogeological management:}

The wetlands in the Mahanadi basin are administered by the hydrological regime of the delta. The water management of the dams, barrages and other interventions undertaken are sectorial in nature. It is focused mainly on structural approaches without considering the subsidence, paucity of sediment, hydrological regime, ecological, short term socioeconomic set up of the delta. Suitable infra-structural long term action plans, experienced reservoir operation methodology, appropriate water shed management and the scientific interstate sharing of the water Mahanadi can ameliorate the Anthropocene hydrologic mismanagement.

\section{Lacking mineralogical management:}

Odisha has more than $35 \%$ of iron ore resources of 5231 million tons. Government of Odisha has signed MOU with 45 numbers new industries of worth 19.455 trillion of INR which fore tails the Industrial wastes shall form new minerals in Odisha in near future. The industrial wastes excreted from the industries in the basin goes wasted and no planned way to handle the waste as a result the districts Raipur, Durg, Jharsuguda, Talcher and Angul shall be under the industrial waste and fly ash

\section{Lacking Solid waste management:}

Domestic, industrial, e-wastes, bio-medical, atomic plant, construction and agriculture solid waste originated must be disposed safely without polluting the environment and the ecosystem. In reality the solid waste management is very poor in the major urban and cities in the Mahanadi basin. Plastic is most polluting and not biodegradable material. Poor water quality and proliferation of aquatic plants in the rivers, Lagoons and water bodies have deteriorated to an extent that neither the water in the distributaries portable not adequate for irrigation. So act as a servant to have Recycle, Reduce, Reuse, Rot and Refuse the wastes. High cost of recycling, exchange of output, involving a closed system (matter and energy), Technology intervention, public aware ness, regulatory frame work and waste reduction activities have poor performance within the basin. The techniques that can be adopted are Separation Waste (Category wise), collection at door to door, weekly collection of garden wastes and annual /seasonal collection of grits, inert, drain silt etc. to have zero solid waste.

\section{Lack in Industrial solid waste management:}

The solid waste from steel industry is blast furnace slags. They can be used for the manufacture of road base, rail/road ballast, cement, light weight concrete (LWC) block, glass, high performance concrete admixtures, back filling materials and artificial rock. At Lanjigarh, in Kalahandi district Odisha, Vedanta has reduced 10-13 $\mathrm{kg}$ of Caustic/ ton of alumina to minimize red mud sludge waste land by $40-50 \%$. The ash ponds in Middle Mahanadi basin are breaching or over topping commonly the agricultural lands are under threat.

\section{Lacking liquid waste management:}

Since there is no incinerator in the Mahanadi basin, and most of the industrial/biomedical wastes are disposed to rivers, the river water gets contaminated with bacteria's and microbes affecting health of people. The liquid waste from domestic, construction, drilling slurry, industries spills and hospitals liquid wastes are neither attenuated or isolated but directly added to storm drains which contaminate the nearby water bodies and drainage channels and finally to the Mahanadi river. Establishment of incinerators is under process for disposal of biomedical waste and the ash from the incinerators to be treated as hazardous waste.

\section{Lacking Anthropogenic gas management:}

The greenhouse gas(GHG) must be called as Anthropogenic gasses and its management is to be done by clean technology in power production, transportation, waste gasses, promoting energy efficiency in building, town planning, economy and enhance climate resilience. Presently the nodal agencies working is the Swachh Bharat Mission, INDCs (Intended nationality determined contribution) under UNFCCC (United Nations convention on climate change) have planned to produce $35 \mathrm{GW}$ (2015) to $175 \mathrm{GW}$ by 2022 as renewable energy, SPVM from $20 \mathrm{GW}$ (2015) to $1000 \mathrm{GW}$ by 2022 . Green energy corridor, energy conservation and smart city concept

\section{Lacking Ecological management:}

Shrinkage of delta is mainly related to mean sea level rise and Hydrologic interventions. Blocking natural flow by large dams, barrages and hydraulic structures plays important role in sediment capture Dandekar (2014) ${ }^{[40]}$. Sediment starved flows erode the beds and levees and deteriorate the sediment regime of the delta. Breaches are common and cause severe flood in the deltas today. Flood inundation, water logging, change in land use and land cover are aggravating the sinking, shrinking and subsidence of deltas Syvitski J. M. et al, 2012 $2^{[41]}$. It has been 
verified that $50 \%$ reduction in chemical fertilizer and adding compost to the fields, stable irrigation but less water shall enhance yield by 15 to $25 \%$ without deteriorating the atmosphere and soil.

\section{Lacking Plastic waste management:}

Disposal, recycling and recovery of plastic waste is to be done as per IS 14534:1998 and PWM Rules and various amendments, 2011, (GOI). The collection should be safe, segregation, storage, transportation and recycling to be done without deteriorating the environment. Public awareness can reduce the use of plastics and recycling as per Environment (Protection) Ad, 1986 management of municipal plastic wastes should be disposed as per Municipal Solid Wastes (Management and Handling) Rules, 2000. Reduce, Recycle, Reuse, Recover, and Residue Management, the 5 R's to be adhered to manage waste to promote ecology, biology and land progression of the area. Use and disposal of plastic should be done not by rule but by human awareness and consciousness.

\section{Poor management of the delta and the lagoon:}

The Mahanadi Delta and the Chilika lagoon is sinking, shrinking and subsiding. Delta management can be done by moderating the inland flow, study of the impact on the coastal ecology proper action plans needs to be implemented. The salinity (both horizontal and vertical mix) is to be maintained by maintaining tidal inlet stability knowing the tectonics, sediment loading and compaction of the Chilika lagoon. The eustatic changes, nutrient dynamics, food budget of the avifauna and aqua fauna of the Chilika lagoon. For Study adequate standardized data to be collected, structural and nonstructural measures to be taken after model and prototype studies to ensure healthy ecosystem of the delta and the lagoon. Structural measures are to be taken to protect the coast line and the spit of the lagoon. For a totality there should have better coordination and well communication between the scientists, Engineers, policy makers and the stakeholders.

\section{Conclusion:-}

The Mahanadi basin was formed during Late Jurassic and Early Cretaceous (1302-107 Ma) had under gone a number of paleo changes and the Chilika Lake transformed from a gulf to a lagoon (3000 years BP). The young juvenile river has become geriatric during the period of Anthropocene due to Human forcing. But 1945 onwards burgeoning demography and anthropogenic activities within the basin have reduced quantum of flow and sediment. The lagoon is also under threat in the acceleration period of the Anthropocene epoch i.e. from 1980. The exponential increase carbon dioxide level, the heat of the sun, Excess mining, the over exploitation of the hydrology and hydrogeology, the ill effects of solid, liquid and industrial waste shall deteriorate the health of the basin further. If the status of the Chilika lagoon is not maintained, it will be converted to dry barren land, ship cemetery like the Aral Sea in Kazakhstan and fresh water swamp Koleru in Andhra Pradesh.

\section{References:-}

1. Crutzen P. J., Stoermer E. F. (2000), The Anthropocene. Global Change News 1. Vol- 41, pp 17-18.

2. Zalasiewicz, J., Cita, M.B., Hilgen, F., Pratt, B.R., Strasser, A., Thierry, J., Weissert, H., 2013. Chronostratigraphy and geochronology: a proposed realignment. GSA Today 23 (3)

3. Mishra S. P., 2017, The apocalyptic Anthropocene epoch and its management in India, Int. Jour. Adv. Research, Vol, 5(3),pp. 645-663

4. Davos-Klosters, 2017, India and the new epoch Livemint, | E-Paper (2004), http://www.livemint.com /Opinion/Tgq73SZ0VH7zc1cX36cfDI/

5. Mishra S. P. and Jena J. G., (2015), "Morphological Reconstruction of Southern Mahanadi Delta and Chilika Lagoon, India - a critical study" Int. Journal of Advanced Research, Volume 3, Issue 5, 691-702

6. Gupta S. M., (2010):" Indian Monsoon Cycles Through The Last Twelve Million Years" Open access eJournal Earth Science India, Vol. 3 (IV, 2010, pp. 248-279, http://www.earthscienceindia.info/;

7. Campisano, C. J. (2012) Milankovitch Cycles, Pale climatic Change, and Hominin Evolution. Nature Education Knowledge 4(3):5

8. Mishra S. P. and Dash Joykrishna (2016) Hydro-morphology of cuts in coastal rivers debouching Chilika ; South Mahanadi Delta, Odisha, India, Int. Journal of Advance Research, Volume 4, Issue 5, pp- 391-404

9. Mishra S. P, 2016, Estuaries and lateral channel development along east coast of India, Int. Journal of Advance Research, Vol. 4(12), pp- 2360-2371

10. Mishra S. P., Das K., 2017, Management of Soil Losses in South Mahanadi Delta, India, International Journal of Earth Sciences and Engineering, 10(02), 222-232, 2017, DOI:10.21276/ijee.2017.10.0213 
11. Delta Development Plan, Government of Odisha, 1986, Report on water Resources Dept Odisha, Vol -3, 1986,Unpublished.

12. Government of India, (2014), The Mahanadi Basin, CWC, Ministry of Water resources, New Delhi and NRSC, ISRO, Department of Space, Hyderabad.

13. Pattanaik, S.,(2001), "Conservation of Environment and Protection of Marginalized Fishing Communities of Lake Chilika in Orissa, India” J. Hum. Ecol., 00(0): 000-000 (0000), JHE 1507, ( Kamla-Raj

14. Chilika Development Authority, (2012), Annual report of Chilika Development Authority 2012" Government of Odisha, BJB Colony Bhubaneswar.

15. Bastia F., Sk. Md. Equeenuddin,2016, Spatio-temporal variation of water flow and sediment discharge in the Mahanadi River, India, Elsevier, Global and Planetary Change, Vol 144, pp- 51-66

16. Bhatta B. P., Moanro, Sarkar B., 2017, Fuel wood characteristics of some important trees and shrubs and emission of carbon dioxide in different states of Eastern India, Taylor and Francis, Energy Sources: Part A, recovery, utilization and env. Effects, Vol 39(4)

17. Chaturvedi B.K., 2016, Why the rural cooking energy infrastructure needs a rethink, https://www.vccircle .com/why-rural-cooking-energy-infrastructure-needs-rethink/

18. Bala Subrahamanya D. et al, (2011):" Impact of Annular Solar Eclipse of 15 January 2010 on the Atmospheric Boundary Layer Characteristics over Thumba: A Case Study", Space Physics Laboratory, Vikram Sarabhai

19. Naik P. K., Pati, G. C., Choudhry A., Naik K. C., 2008, Conservation of Chilika lake Odisha, India, Sengupta M. and Dalwani R. (Editors), Proceedings of Taal 12th world lake conference, pp. 1988-1992

20. Jena P. P., Chatterjee C., Pradhan G., Mishra A., 2014, "Are recent frequent high floods in Mahanadi basin in eastern India due to increase in extreme rainfalls?”, Elsevier, Journal of Hydrology 517, pp. 847-862

21. Fadnavis S., , K. Ravi Kumar, Tiwari Y. K., and Pozzoli L., 2016, Atmospheric CO2 source and sink patterns over the Indian region, Ann. Geophys., 34, 279-291, www.ann-geophys.net/34/279/2016/ doi: 10.5194/angeo34-279-2016

22. Ghose, D. K., Swain, P. K.: (2011), "Erosion and sediment characteristics of peninsular rivers India, a case study", International Journal of Engineering Science and Technology (IJEST), ISSN : 0975-5462 Vol. 3 No. 5, PP- 3716 to 3725

23. Lidija Globevnik, Holzevic D., Petkovsek G, Rubinic J.,(2003), “Applicability of the Gavrilovic method in erosion calculation using spatial data manipulation techniques, erosion prediction in un-gauged basins : Integrating methods and techniques", Proceedings of symposium HS01 held during IUGG 2003 at Sapporo, July 2003, IAHS Publication No 279, 2003.

24. Syvitski, J.P.M., Vörösmarty, C.J., Kettner, A.J., and Green, P., 2005, Impact of humans on the flux of terrestrial sediment to the global coastal ocean: Science, v. 308, p. 376-380, doi: 10.1126/science.1109454.

25. Syvitski et al, Sinking deltas due to human activities, Nature Geoscience, 2009

26. Gupta H, Shuh-Ji Kao, Minhan Dai,, 2012, The role of mega dams in reducing sediment fluxes: A case study of large Asian rivers, Journal of Hydrology, 2012

27. Chakrapani, G. J., 2014, Mahanadi River Basin, Chapter 2,9 and11, Sodhaganga, Shodhganga.inflib net.ac.in/handle/10603/1510

28. Mohanti M., Swain M. R.,2005, Mahanadi river delta, an overview of evolution and dynamic processes, 2005, sklec. ecnu. edu .cn/ mega delta/ main/ upload/ Mahanadi. pd

29. Rao P. G.,( 2009), Effect of Climate Change on Stream flows in the Mahanadi River Basin, India, Taylor and Francis, Water International, Vol 20, pp.205-212

30. IPCC report (AR 5), 2014: Climate Change (2014): Synthesis Report. Contribution of Working Groups I, II and III to the Fifth Assessment Report of the Intergovernmental Panel on Climate Change [Core Writing Team, R.K. Pachauri and L.A. Meyer (eds.)]. IPCC, Geneva, Switzerland, 151 pp.

31. Asokan S. M. and Dutta D.(2008),, "Analysis of water resources in the Mahanadi River Basin, India under projected climatic conditions", Hydrological processes, Volume 22, Issue 18, page 3589-3603, John Wiley \& Sons, Ltd,

32. Ramachandra T.V., Shwetmala, (2012), Decentralized carbon footprint analysis for opting climate change mitigation strategies in India, ELSEVIER, Renewable and Sustainable Energy Reviews 16, 5820-5833

33. Goenka Debi, Coal Kills, 2014 An Assessment of Death and Disease caused by India's Dirtiest Energy Source CAT<debi@cat.org.in> and Sarath Guttikunda, Urban Emissions, 2013

34. Hossetti B. B., A. Kumar, (1998), Environmental Impact assessment and management, Daya Publishing House, new Delhi, http://www.vccircle.com/byinvitation/2016/04/28/why-rural-cooking-energy-infrastructure -needsrethink 
35. Senapati M. R.,( 2011), Fly ash from thermal power plants - waste management and overview, Current Science, Vol. 100, (12), PP. 1791-1794

36. Yadav A., Rajhans1 K. P., Ramteke S., Sahu B. L., Patel K. S., Blazhev B., 2016, Contamination of Industrial Waste Water in Central India, Journal of Environmental Protection, 2016, 7, 72-81 http://www. scirp.org/journal/jep.

37. Tchounwou P. B, Yedjou C. G, Patlolla A. K, and Sutton D. J.,( 2014), Heavy Metals Toxicity and the Environment, PMC, US National Library of Medicine National Institutes of Health

38. Mohod C. V., Dhote J., 2013, Review of heavy metals in drinking water and their effect on human health, International Jour of Innovative Research in Science, Eng. and Tech., Vol. 2,(7), pp. 2992-2996,

39. Carolyn Gramling,( 2017), 3.77-billion-year-old fossils stake new claim to oldest evidence of life, Science, http://www.sciencemag.org/news/2017/03/377, Posted in: Archaeology Earth, DOI: 10.1126/science.aal0843

40. Dandekar P. ,( 2014), Shrinking and Sinking Deltas: Major role of Dams in delta subsidence and effective sea level rise, South Asian network on Dams Rivers and People, http://sandrp.in/, http://sandrp.wordpress. Com., pp $-1-16$

41. Syvitski J. P.M. , Overeem I, , Brakenridge G. R., Hannon M., (2012) "Floods, floodplains, delta plains -A satellite imaging approach", ELSIVER, Sedimentary Geology doi:10.1016/j.sedgeo.2012. 